\title{
Windfall gains and labour supply: evidence from the European household panel
}

\author{
Urban Sila ${ }^{1 *}$ and Ricardo M Sousa ${ }^{2,3}$
}

\author{
* Correspondence: \\ urban.sila@oecd.org \\ ${ }^{1} \mathrm{OECD}, 2$ rue Andre Pascal, 75775 \\ Paris Cedex 16, France
}

\begin{abstract}
We investigate whether workers adjust hours worked in response to windfall gains using data from the European Household Panel. The results suggest that a rise in unearned income has a negative (although small) effect on working hours. In particular, after receiving a windfall gain, individuals are more likely to drop out of the labour force and the effects become larger as the size of windfall increases. Furthermore, the empirical findings show that the impact of windfall gains on labour supply: (i) is more important for young and old individuals, (ii) is most negative for married individuals with young children, (iii) but can be positive for single individuals without children at the age of around 40 years. The latter effect can be explained by individuals using the windfall gain to set up their own business and become self-employed.

JEL classification: D12, J22.

Keywords: Windfall gains; Working hours
\end{abstract}

\section{Introduction}

What is the effect of windfall gains on economic behaviour? A popular belief presumes that the majority of people would quit work if they won a lottery. But do windfall gains have an impact on individuals' working hours?

According to the life-cycle model, a relaxation or tightening of the consumer's intertemporal budget constraint can lead to changes in labour supply. Windfall gains represent an unanticipated increase in non-earned income and, by reducing the marginal utility of wealth, they diminish the agent's incentive to work.

While the literature on the empirical and theoretical inter-temporal substitution effects in labour supply is well established (Heckman and MaCurdy 1980), the research on the impact of capital gains is still somewhat insipient, despite the fact that lottery winnings are a source of exogenous variation in income (Altonji 1986).

In the US, Kaplan (1988) shows that the level of education and the type of profession can help explain the share of winners that choose to continue to work. Holtz-Eakin et al. (1993) and Imbens et al. (2001) find that windfall gains reduce working hours or even lead to a withdrawal from the labour force (especially, in the case of older individuals). In contrast, Joulfaian and Wilhelm (1994) suggest, at most, a small (although significant) effect of inheritances on labour supply of married women and men.

In Europe, Burke et al. (1997) evaluate the effects of inheritances on the job creation of self-employment enterprises, and show that it plays an important role. Blanchflower 
and Oswald (1998) use data for the UK and argue that individuals receiving inheritances are more likely to be self-employed than those not receiving an inheritance. This is also expressed in the large fraction of individuals who do not become self-employed because of their inability to raise the necessary financial resources. Also for the UK, Taylor (2001) reports a positive effect of windfall gains (inheritance and lottery wins) on the probability of entering self-employment. The author emphasizes that liquidity constraints can be detrimental for starting a new business, for the growth of entrepreneurships and for the success of small businesses. Henley (2004) analyzes the impact of both windfall financial gains and house price shocks on hours worked, and suggests that there are significant substitution effects, in particular, in response to house price shocks.

In this paper, we analyses the linkages between windfall gains and working hours using data from the European Community Household Panel Longitudinal Users' Database. In accordance with the life-cycle model, we show that an unanticipated rise in wealth reduces working hours, although the effect is, in general, small. The impact of windfall gains is stronger at the external margin, that is, individuals adjust their labour supply primarily by dropping out of the labour force, rather than by reducing their working hours, conditional on working.

We also assess whether the size of the windfall gain matters, i.e. we evaluate how working hours respond to small, medium and large windfall gains. We find that the effects become stronger as the size of the windfall increases. In particular, men receiving a windfall of 50,000 EUR or more, on average reduce labour supply by 1.3 hours per week, which is equivalent to a $3.4 \%$ reduction in working hours.

Finally, analysing the effects of windfall gains along various personal characteristics, we show that: (i) at younger and older ages, the effect of windfall gains on labour supply is the most negative; (ii) for married people and people with young children, the windfall gain leads to a stronger decrease in working hours; and (iii) for single individuals at the age of around 40, the effect can be positive. A potential explanation for the latter finding is the effect of windfall gains on reducing liquidity constraints. By doing so, windfall gains may encourage people to set up their own businesses, become selfemployed and increase their working hours. Alternatively, in the light of the fact that richer families are more likely to give inheritances, individuals from richer families may also be more likely to start their own businesses.

We contribute to the literature in following ways. First, we analyse the effects of windfall gains on working hours using data for a set of European countries, rather than focusing on one-country data. Second, we include 15 countries in our framework and, therefore, the sample of people for which we observe windfall gains is large, offering a further empirical advantage to our approach. Third, with the panel dataset, we observe a rich set of personal characteristics of individuals. This gives us an opportunity to better understand the ways that participation and working-hours decisions differ between individuals. Finally, given that the panel dataset covers a relatively long sample period, we can account for the time-variation in labour supply, a feature that would not be captured in a cross-sectional study.

The remainder of the paper is structured as follows. Section 2 describes the data. Section 3 presents the econometric approach. Section 4 discusses the empirical results. Section 5 concludes. 


\section{Data and descriptive statistics}

\subsection{Data}

The data is obtained from the European Community Household Panel Longitudinal Users' Database (ECHP henceforth). This is a large panel data set that contains household-level and person-level information over time, covering eight survey years from 1994 to $2001^{1}$. The data includes 15 EU countries: Germany, Denmark, The Netherlands, Belgium, Luxembourg, France, United Kingdom, Ireland, Italy, Greece, Spain, Portugal, Austria, Finland and Sweden. It is an unbalanced panel with a maximum length of 8 years for each individual ${ }^{2}$.

In what follows, the analysis is done at the individual level, rather than at the level of households, with age restricted to 25-60 years ${ }^{3}$. This age band is set in order to avoid complications that arise due to education and retirement choices ${ }^{4}$. The data on incomes and wages are converted using purchasing power parity (PPP) in order to allow for comparisons across countries and over time.

The question of interest relates to the effects of unanticipated windfall gains on labour supply. Working hours are described by the ECHP variable PE005: Total number of hours working per week (in main + additional jobs). In the data, this variable is only available for employed workers. However, we set hours worked to zero for all unemployed individuals and those out of the labour force.

The variable that measures windfall gains is the ECHP variable HF017: Inherit, receive gift or lottery winnings worth 2000 EURO or more. It is the response to a following survey question: "During (... year prior to the survey ...), did anyone in the household inherit any property or capital, or receive a gift or lottery winnings, worth 2000 EURO or more?". Observations for which the information on the windfall receipt is missing are discarded.

One major drawback of this variable is that it does not provide information about the exact amount of the windfall gain. However, it can be complemented by the variable HF018: Amount of the inheritance, gift or lottery winnings. This variable offers three brackets for the windfall gains: less than 10,000 EURO, more than 10,000 EURO but less than 50,000 EURO and 50,000 EURO or more. We label the three brackets for windfall gains as "small", "medium" and "large", respectively.

These two variables hence give information on the size of windfall gains received by individuals. Nevertheless, given that they are reported in categorical terms, one cannot convert them into PPP terms. As a result, they are not perfectly comparable across countries and over time. Another weakness is that both variables are reported at the household level. Consequently, there is no way to identify which household member was the actual recipient of the windfall gain ${ }^{5}$.

It is important to emphasise that the variable measuring windfall gains is recorded for the "year prior to the survey" ${ }^{6}$. Despite this, we did not adjust the timing of the variable for various reasons. First, a substantial fraction of the data (that is, 19\% of personyear observations) would be lost by lagging the windfall gains variable by one period. Second, leaving the variable as it is, we can be sure that at the time of the interview in the time period $t$, an individual knows whether she has received windfall gains or not. On the contrary, if we lagged windfall gains variable by one period, to $t-1$, we would not know for sure whether at the time of the interview at $t-1$ the individual had already received the windfall gains or not $^{7}$. Furthermore, in practice individuals take a bit of 
time before they react to new economic information. Therefore, it seems more appropriate not to lag the windfall gains variable back by one period.

Another drawback of our measure of windfall gains is that it includes gifts and inheritances, which can be anticipated to some degree. This especially holds for individuals from wealthy families. If they anticipate large gifts or inheritances to occur soon, they may adjust their labour supply prior to the actual receipt. Holtz-Eakin et al. (1993) find that individuals receiving a larger inheritance are more likely to leave the labour force, because leisure is a normal good. The negative effect of inheritances on labour supply holds, even when participation remains unchanged. Joulfaian and Wilhelm (1994) argue that an inheritance is a disincentive to labour, because it negatively impacts on future marginal utility of wealth. When unanticipated, it can lead to an upward revision of expected lifetime wealth and a discontinuous drop in marginal utility of wealth and, thus, in labour supply. If anticipated, the fall in marginal utility of wealth over the economic life would imply a downward shift in the entire life-cycle profile of labour. Joulfaian (2006) looks at the impact of inheritances on savings, and shows that wealth increases by only a fraction of the full amount of the inheritance received. More recently, Brown et al. (2010) use the receipt of inheritances as a proxy for wealth shocks and finds that it significantly increases the probability of retirement, in particular, in the case of unexpected inheritances.

Despite this, since our measure of windfall gains is anticipated to some degree, the estimated impact of windfall gains on labour supply will underestimate the true effect. Therefore, our estimates can be thought of as being at the lower end of the "true" effect.

To ease discussion, we label people that have received windfall gains as "winners" and the rest as "non-winners". If we only include individuals who were observed at least twice over time, there are 100,289 individuals in our sample. Most of them (88.4\%) never received any inheritance, gift or lottery winnings of more than 2000 EUR. 8,824 individuals (or a fraction of $8.8 \%$ ) received windfall gains only once, and about $2.8 \%$ of individuals received windfall gains more than once. Because in the regression analysis it is not straightforward to deal with individuals who received windfall gains more than once we include in our empirical analysis only individuals who received windfall gains once. Compared to similar research done by other authors, this is quite a large sample and represents one of the advantages of using the ECHP dataset ${ }^{8}$.

By size of windfall gains received, there are 4,172 (48.8\%) observed individuals with small windfall gains, 3,353 (39.2\%) with medium windfall gains, and 1,023 (12.0\%) individuals with large windfall gains.

\subsection{Descriptive statistics}

We briefly look at differences in personal characteristics between winners and nonwinners prior to the receipt of windfall gains. Table 1 reports the means and number of observations for selected variables, comparing winners, (columns (1) and (2)) and nonwinners (columns (3) and (4)). Column (5) reports the $p$-value of the test for differences in means between winners and non-winners. The reported statistics refer to one year before the receipt of windfall, which, on average, corresponds to a third year in the sample for winners. Therefore, for non-winners we report the means of the variables in the third year in the sample. 
Table 1 Comparing personal information for winners and non-winners (prior to receiving windfall gains)

\begin{tabular}{|c|c|c|c|c|c|}
\hline \multirow[b]{2}{*}{ Variable } & \multicolumn{2}{|c|}{$\begin{array}{l}\text { Have received } \\
\text { windfall gains }\end{array}$} & \multicolumn{2}{|c|}{$\begin{array}{l}\text { Have not received } \\
\text { windfall gains }\end{array}$} & \multirow{2}{*}{$\begin{array}{c}\text { Diff. in means } \\
p \text {-value } \\
\text { (5) }\end{array}$} \\
\hline & $\begin{array}{c}\text { Mean } \\
(1)\end{array}$ & $\begin{array}{l}\text { Obs. } \\
(2)\end{array}$ & $\begin{array}{c}\text { Mean } \\
\text { (3) }\end{array}$ & $\begin{array}{l}\text { Obs. } \\
\text { (4) }\end{array}$ & \\
\hline Household size & 3.29 & 6,674 & 3.46 & 75,040 & 0.000 \\
\hline Number of adults $(>16)$ in household & 2.45 & 6,674 & 2.63 & 75,040 & 0.000 \\
\hline Number of children $(16<)$ in household & 0.84 & 6,674 & 0.83 & 75,040 & 0.739 \\
\hline Age & 42.01 & 6,674 & 41.23 & 75,040 & 0.000 \\
\hline Female dummy & 0.51 & 6,674 & 0.51 & 75,040 & 0.484 \\
\hline Married dummy & 0.73 & 6,664 & 0.72 & 74,974 & 0.249 \\
\hline Secondary education dummy & 0.38 & 6,576 & 0.36 & 73,598 & 0.000 \\
\hline Post secondary education dummy & 0.29 & 6,576 & 0.18 & 73,598 & 0.000 \\
\hline Employed dummy & 0.77 & 6,656 & 0.70 & 74,998 & 0.000 \\
\hline Household income & 31,186 & 6,648 & 25,863 & 74,584 & 0.000 \\
\hline Household income - from working & 26,758 & 6,651 & 21,337 & 74,598 & 0.000 \\
\hline Household income - unearned income & 1,448 & 6,651 & 848 & 74,598 & 0.000 \\
\hline Personal income & 15,589 & 6,674 & 12,095 & 75,040 & 0.000 \\
\hline Personal income - from working & 13,270 & 6,674 & 10,222 & 75,040 & 0.000 \\
\hline Personal income - unearned income & 690 & 6,674 & 376 & 75,040 & 0.000 \\
\hline Personal hourly wage & 7.68 & 6,674 & 6.78 & 75,040 & 0.000 \\
\hline Total hours working per week & 30.57 & 6,497 & 28.26 & 73,932 & 0.000 \\
\hline
\end{tabular}

Source: European Community Household Panel Longitudinal Users' Database. All individuals of age 25-60. Winners are observed one period before receiving windfall gains. This approximately corresponds to period 3 in the sample for non-winners.

Among the 18 variables reported, only three (the number of children in the household, the percentage of women and the percentage of those who are married) have differences that are not statistically significant ${ }^{9}$. Otherwise, winners tend to be older and they live in slightly smaller households, but for these two variable differences are small. For the rest of the variables, the differences are large and important.

Winners are more educated; the share of individuals with post secondary education is $29 \%$ for winners and $18 \%$ for non-winners; winners are 7 percentage points more likely to be employed than non-winners. According to income variables, winners have higher incomes and wages even before windfall gains. By all measures of income (total income, income from working and non-work income), winners are better off than non-winners: the personal total income of winners is about $29 \%$ higher and hourly wage ${ }^{10}$ is $13 \%$ higher. Higher income is partly a consequence of the fact that winners, on average, work more hours per week and they are more likely to be employed. They are also more educated and thus have higher hourly wage. However, another potential reason for the difference in incomes lies also in the fact that our measure of windfall gains includes gifts and inheritances. It can thus be the case that people from better family backgrounds are more likely to receive (large) gifts or inheritances, which is reflected in our data. Family background is of course an individual fixed effect and will eventually drop out of the analysis using fixed effects panel estimation ${ }^{11}$. 


\subsection{Non-work income over time}

In this sub-section, we show the evolution of unearned income over time. The motivation for this is to verify whether the windfall gains variable that we use is a good measure. In Figure 1, we depict the average (household and personal) non-work income over time ${ }^{12}$. The time period " 0 " refers to a time of windfall gains receipt. Since the maximum number of periods for an individual in the sample is eight, the graph is plotted only for five years prior and five years after the receipt of windfall gains. Moving further away from the point of receipt would make the sample size become very small. From the Figure, it can be seen that the variable windfall gains is meaningful and informative. Indeed, there is a positive blip in both household and personal non-work income at the time of receipt. After that, non-work income returns to its upward trend ${ }^{13}$.

\section{Econometric approach}

Despite the large literature concerned with estimating the impact of unearned income on labour supply, the use of an exogenous measure of income variation is not consensual. As a result, different approaches have been considered, namely: (i) the capital income or spousal-labour earnings as variables measuring unearned income (Imbens et al. 2001); (ii) experimental data with exogenous components of unearned income (Pencavel 1986); and (iii) natural experiments in which large amounts of money were allocated using distribution rules that were independent of preferences and other determinants of economic behaviour (Bodkin 1959; Holtz-Eakin et al. 1993).

We start by looking at whether the windfall gain affects the probability of being employed, and estimate the following linear probability model

$$
\operatorname{Prob}\left(\mathrm{E}_{\mathrm{it}}=1\right)=\mathrm{b}_{0}+\mathrm{b}_{0 \mathrm{i}}+b_{\mathrm{i}} \text { Wingfalls }_{i t}+b_{2} W_{i t}+b_{3} X_{i t}+\varepsilon_{i t}
$$

for $i=1, \ldots, N, t=1, \ldots, T$, where $E_{i t}$ is a dummy variable that takes the value of 1 if individual $i$ is employed or 0 otherwise, Windfall $_{i t}$ is our variable of interest and takes the

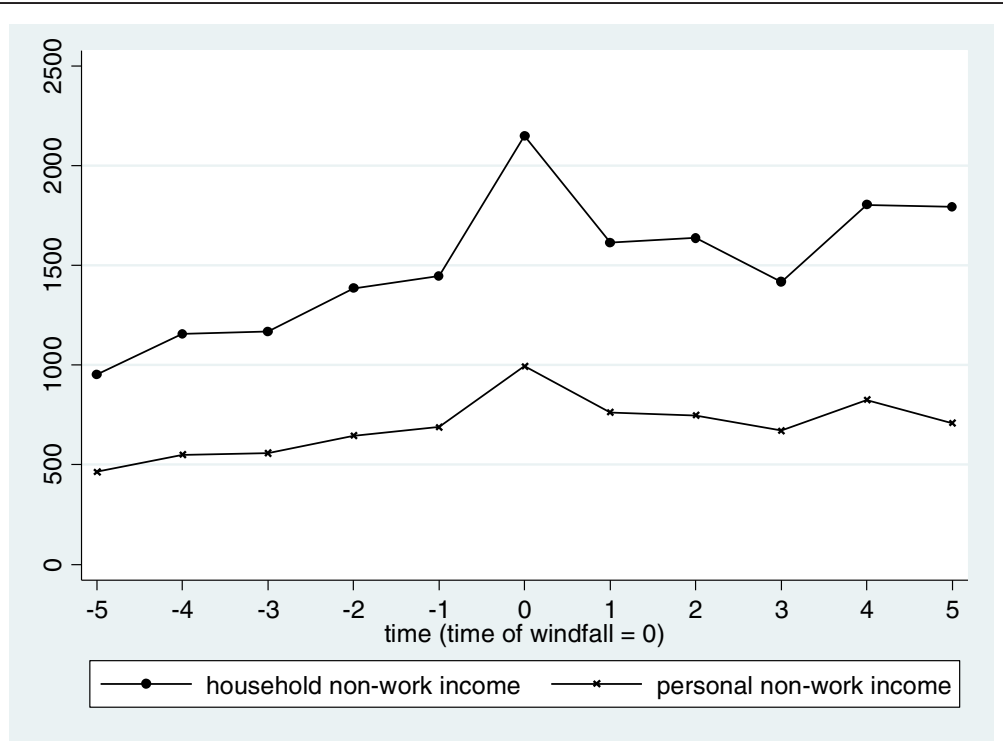

Figure 1 Non-work income over time for those who received windfall gains. Source: European Community Household Panel Longitudinal Users' Database. Individuals who received windfall gains of age 25-60. Time period 0 is period when windfall gains were received. 
value of 1 if the household has received a windfall gain or 0 otherwise, $W_{i t}$ denotes the hourly wage, $\boldsymbol{X}_{\boldsymbol{i} \boldsymbol{t}}$ represents a set of controls for age, civil status and family characteristics, $\mathrm{c}_{0 \mathrm{i}}$ is individual fixed effect and $\varepsilon_{i t}$ is an i.i.d. error term.

In order to assess the effect of unexpected capital gains on working hours, we estimate the empirical counter-part of Equation (1) as described by

$$
\mathrm{H}_{\mathrm{it}}=\mathrm{c}_{0}+\mathrm{c}_{0 \mathrm{i}}+\mathrm{c}_{1} \text { Windfall }_{i t}+c_{2} W_{i t}+c_{3} X_{i t}+\varepsilon_{i t}
$$

for $i=1, \ldots, N, t=1, \ldots, T$, where $H_{i t}$ stands for weekly working hours of household $i$ in year $t$.

Taking into account that the impact of windfalls on labour supply differs for different amounts of unanticipated gains, we also disaggregate the Windfall dummy into three different categories: (i) Small Windfall, in the case of capital gains between 2,000 and 10,000 EUR; (ii) Medium Windfall, for capital gains between 10,000 and 50,000 EUR; and (iii) Large Windfall, when the capital gain exceeds 50,000 EUR. Then, we consider the model:

$$
\begin{aligned}
\mathrm{H}_{\mathrm{it}}= & \mathrm{c}_{0}+\mathrm{c}_{0 \mathrm{i}}+c_{1}^{1} \text { Small Windfall }_{i t}+c_{1}^{2} \text { Medium Windfall }_{i t}+c_{1}^{3} L \operatorname{arge} \text { Windfall }_{i t}+ \\
& +c_{2} W_{i t}+c_{3} X_{i t}+\varepsilon_{i t}
\end{aligned}
$$

for $i=1, \ldots, N, t=1, \ldots, T$.

Finally, we look at whether the effect of the windfall varies with different personal characteristics. Therefore, we interact the regressors with the Windfall dummy and estimate the following model:

$$
\begin{aligned}
\mathrm{H}_{\mathrm{it}}= & \mathrm{c}_{0}+\mathrm{c}_{0 \mathrm{i}}+c_{1} \text { Windfall }_{i t}+c_{2} W_{i t} \times\left(1+\text { Windfall }_{i t}\right)+c_{3} X_{i t} \\
& \times\left(1+\text { Windfall }_{i t}\right)+\varepsilon_{i t}
\end{aligned}
$$

for $i=1, \ldots, N, t=1, \ldots, T$.

The estimation of the above models is complicated by the potential endogeneity of the wage term on the right-hand side ${ }^{14}$. Altonji (1986) emphasizes that current labour supply depends on all past and expected future wage rates and that it is important to control for permanent differences in wages across individuals.

Consequently, we assess the robustness of the results using both the fixed effects (FE) estimator and the fixed effects instrumental variable (FE-IV) estimator. This allows us to identify the effect of unearned income on labour supply through exogenous changes and the subsequent behaviour of individuals observed in the panel ${ }^{15}$. In the IV regressions, we follow Joulfaian and Wilhelm (1994) and Henley (2004) and instrument log hourly wages using conventional earnings-function control variables, namely, two dummies for education, interactions between education dummies and a quadratic in age, as well as country-year dummies.

\section{Empirical results}

\subsection{The effects of windfall gains on working hours}

In this and subsequent sub-sections, we analyse the effect of windfall gains on working hours. We use the fixed effects estimation, thus controlling for family background and other time-invariant personal characteristics. Windfall gains are measured using a dummy variable that takes a value of 1 in the period of windfall receipt and after, and 0 
in periods prior to windfall gains. This is in line with the life-cycle model of labour supply where after an unanticipated shock in personal wealth, an individual adjusts her whole labour-supply profile.

In all specifications we include the following set of regressors: the dummy variable for the windfall gain, age, age squared, a dummy for married status and two dummy variables indicating whether there are any children aged $0-6$ or 7-15 in the household. We focus on three main specifications, each of them being estimated for the full sample (Table 2), and then separately for men (Table 3 ) and for women (Table 4).

The first specification (Column (1)) analyses the effects of windfall gains on the probability of being employed. According to the theory, after receiving unanticipated windfall gains, individuals are more likely to drop out of the labour force and use windfall gains to enjoy more leisure. Such behaviour is reported in Holtz-Eakin et al. (1993), who find a negative effect of unanticipated inheritances on participation in the labour market. As a dependent variable we use a dummy variable indicating whether or not an individual is employed ${ }^{16}$. Normally, probit specification would be used to analyse this;

Table 2 Effects of windfall gains on working hours - all

\begin{tabular}{|c|c|c|c|c|c|}
\hline \multirow[t]{3}{*}{ Dependent variable: } & \multirow{3}{*}{$\begin{array}{c}\text { Employment } \\
\text { dummy } \\
\text { (1) } \\
\text { FE }\end{array}$} & \multicolumn{2}{|c|}{$\begin{array}{l}\text { Working hours } \\
\text { per week }\end{array}$} & \multicolumn{2}{|c|}{$\begin{array}{l}\text { Log working hours } \\
\text { per week }\end{array}$} \\
\hline & & (2) & (3) & (4) & (5) \\
\hline & & $\mathrm{FE}$ & FE IV & $\mathrm{FE}$ & FE IV \\
\hline \multirow[t]{2}{*}{ Windfall gains dummy } & -0.00424 & -0.0618 & 0.00194 & 0.00125 & 0.00236 \\
\hline & $(0.00360)$ & $(0.159)$ & $(0.161)$ & $(0.00365)$ & $(0.00375)$ \\
\hline \multirow[t]{2}{*}{ Hourly wage } & & $-0.831^{* * *}$ & $-0.441^{* *}$ & & \\
\hline & & $(0.0262)$ & $(0.203)$ & & \\
\hline \multirow[t]{2}{*}{ Log hourly wage } & & & & $-0.404^{* * *}$ & $-0.197^{* * *}$ \\
\hline & & & & $(0.00610)$ & $(0.0469)$ \\
\hline \multirow[t]{2}{*}{ Age } & $0.0823^{* * *}$ & $3.876^{* * *}$ & $3.625^{* * *}$ & $0.0564^{* * *}$ & $0.0386^{* * *}$ \\
\hline & $(0.00272)$ & $(0.121)$ & $(0.150)$ & $(0.00295)$ & $(0.00464)$ \\
\hline \multirow[t]{2}{*}{$\mathrm{Age}^{\wedge} 2$} & $-0.000986^{* * *}$ & $-0.0452^{* * *}$ & $-0.0439^{* * *}$ & $-0.000490^{* * *}$ & $-0.000391^{* * *}$ \\
\hline & (3.09e-05) & $(0.00137)$ & $(0.00142)$ & (3.40e-05) & $(3.88 e-05)$ \\
\hline \multirow[t]{2}{*}{ Married dummy } & $0.0129^{*}$ & $1.205^{* * *}$ & $1.157^{* * *}$ & $0.0146^{* *}$ & 0.00932 \\
\hline & $(0.00680)$ & $(0.301)$ & $(0.312)$ & $(0.00671)$ & $(0.00708)$ \\
\hline \multirow{2}{*}{$\begin{array}{l}\text { Children 0-6 in } \\
\text { household dummy }\end{array}$} & $-0.0516^{* * *}$ & $-2.841^{* * *}$ & $-2.961^{* * *}$ & $-0.0491^{* * *}$ & $-0.0534^{* * *}$ \\
\hline & $(0.00571)$ & $(0.253)$ & $(0.259)$ & $(0.00560)$ & $(0.00584)$ \\
\hline \multirow{2}{*}{$\begin{array}{l}\text { Children } 7-15 \text { in } \\
\text { household dummy }\end{array}$} & $-0.0425^{* * *}$ & $-2.318^{* * *}$ & $-2.333^{* * *}$ & $-0.0293^{* * *}$ & $-0.0292^{* * *}$ \\
\hline & $(0.00519)$ & $(0.230)$ & $(0.233)$ & $(0.00518)$ & $(0.00533)$ \\
\hline \multirow[t]{2}{*}{ Constant } & $-0.841^{* * *}$ & $-41.45^{* * *}$ & $-36.29^{* * *}$ & $2.974^{* * *}$ & $3.131^{* * *}$ \\
\hline & $(0.0589)$ & $(2.615)$ & (3.089) & $(0.0617)$ & $(0.0680)$ \\
\hline Observations & 54164 & 53011 & 52348 & 40239 & 39789 \\
\hline Number of individuals & 10395 & 10357 & 10322 & 8735 & 8700 \\
\hline R-squared & 0.024 & 0.049 & & 0.126 & \\
\hline Hausman test ${ }^{+}$ & & & 0.000 & & 0.000 \\
\hline
\end{tabular}

Standard errors in parentheses, ${ }^{*}$ significant at $10 \%$; ${ }^{* *}$ significant at $5 \%$; ${ }^{* * *}$ significant at $1 \% .{ }^{+}$Reports $p$-value of the Hausman test of endogeneity. In IV regression (log) hourly wage is instrumented using two dummies for education, interactions between education dummies and quartic in age and country-year dummies. All regressions include individual fixed-effects. 
Table 3 Effects of windfall gains on working hours - men

\begin{tabular}{|c|c|c|c|c|c|}
\hline \multirow[t]{3}{*}{ Dependent variable: } & \multirow{2}{*}{$\begin{array}{l}\text { Employment } \\
\text { dummy } \\
\text { (1) }\end{array}$} & \multicolumn{2}{|c|}{$\begin{array}{l}\text { Working hours } \\
\text { per week }\end{array}$} & \multicolumn{2}{|c|}{$\begin{array}{l}\text { Log working hours } \\
\text { per week }\end{array}$} \\
\hline & & (2) & (3) & (4) & (5) \\
\hline & $\mathrm{FE}$ & $\mathrm{FE}$ & FE IV & $\mathrm{FE}$ & FE IV \\
\hline \multirow[t]{2}{*}{ Windfall gains dummy } & -0.00493 & -0.158 & -0.0525 & 0.00126 & 0.00130 \\
\hline & $(0.00443)$ & $(0.237)$ & $(0.239)$ & $(0.00398)$ & $(0.00408)$ \\
\hline \multirow[t]{2}{*}{ Hourly wage } & & $-0.879^{* * *}$ & $-0.812^{* * *}$ & & \\
\hline & & $(0.0360)$ & $(0.218)$ & & \\
\hline \multirow[t]{2}{*}{ Log hourly wage } & & & & $-0.368^{* * *}$ & $-0.192^{* * *}$ \\
\hline & & & & $(0.00704)$ & $(0.0462)$ \\
\hline \multirow[t]{2}{*}{ Age } & $0.0955^{* * *}$ & $5.188^{* * *}$ & $5.064^{* * *}$ & $0.0621^{* * *}$ & $0.0471^{* * *}$ \\
\hline & $(0.00338)$ & $(0.181)$ & $(0.205)$ & $(0.00323)$ & $(0.00490)$ \\
\hline \multirow[t]{2}{*}{ Age $\wedge 2$} & $-0.00115^{* * *}$ & $-0.0602^{* * *}$ & $-0.0593^{* * *}$ & $-0.000580^{* * *}$ & $-0.000495^{* * *}$ \\
\hline & $(3.83 e-05)$ & $(0.00205)$ & $(0.00208)$ & $(3.69 e-05)$ & $(4.23 e-05)$ \\
\hline \multirow[t]{2}{*}{ Married dummy } & $0.0197^{* *}$ & $2.126^{* * *}$ & $2.050^{* * *}$ & $0.0349^{* * *}$ & $0.0293^{* * *}$ \\
\hline & $(0.00843)$ & $(0.449)$ & $(0.460)$ & $(0.00748)$ & $(0.00785)$ \\
\hline \multirow{2}{*}{$\begin{array}{l}\text { Children 0-6 in } \\
\text { household dummy }\end{array}$} & $-0.0309^{* * *}$ & $-1.207^{* * *}$ & $-1.406^{* * *}$ & 3.02e-05 & -0.00319 \\
\hline & $(0.00684)$ & $(0.366)$ & $(0.372)$ & $(0.00602)$ & $(0.00625)$ \\
\hline \multirow{2}{*}{$\begin{array}{l}\text { Children } 7-15 \text { in } \\
\text { household dummy }\end{array}$} & $-0.0356^{* * *}$ & $-1.497^{* * *}$ & $-1.579^{* * *}$ & -0.00605 & -0.00580 \\
\hline & $(0.00640)$ & $(0.341)$ & $(0.346)$ & $(0.00566)$ & $(0.00582)$ \\
\hline \multirow[t]{2}{*}{ Constant } & $-0.980^{* * *}$ & $-59.98^{* * *}$ & $-56.94^{* * *}$ & $2.959^{* * *}$ & $3.076^{* * *}$ \\
\hline & $(0.0733)$ & (3.925) & $(4.335)$ & $(0.0679)$ & $(0.0738)$ \\
\hline Observations & 26176 & 25626 & 25327 & 22503 & 22278 \\
\hline Number of individuals & 5087 & 5073 & 5061 & 4691 & 4679 \\
\hline R-squared & 0.044 & 0.070 & & 0.140 & \\
\hline Hausman test $^{+}$ & & & 0.000 & & 0.008 \\
\hline
\end{tabular}

Standard errors in parentheses, *significant at 10\%; ${ }^{* *}$ significant at 5\%; ${ }^{* * *}$ significant at $1 \% .{ }^{+}$Reports p-value of the Hausman test of endogeneity. In IV regression (log) hourly wage is instrumented using two dummies for education, interactions between education dummies and quartic in age and country-year dummies. All regressions include individual fixed-effects.

however, due to inconsistency of probit regression in settings with fixed effects, we use a linear probability model instead ${ }^{17}$.

The second specification (Column (2)) uses working hours per week as a dependent variable. In this case we include all individuals who ever received windfall gains regardless of whether they participate in the labour force in any particular period or not. That is, working hours can take any positive value, but they can also be zero. The second specification thus covers both external and internal margins of adjustment of labour supply to windfall gains. In addition to the standard controls on the right hand side, this specification also includes a measure of hourly wage. As the hourly wage is computed from monthly wages and weekly working hours, it is endogenous. Consequently, we also report the results from instrumental variables estimation (Column (3)). Here we overcome the endogeneity problem by using two dummies for education, interactions of education dummies with quartic in age, as well as country-year dummies as instruments for hourly wage. 
Table 4 Effects of windfall gains on working hours - women

\begin{tabular}{|c|c|c|c|c|c|}
\hline \multirow[t]{3}{*}{ Dependent variable: } & \multirow{3}{*}{$\begin{array}{l}\text { Employment } \\
\text { dummy } \\
\text { (1) } \\
\text { FE }\end{array}$} & \multicolumn{2}{|c|}{$\begin{array}{l}\text { Working hours } \\
\text { per week }\end{array}$} & \multicolumn{2}{|c|}{$\begin{array}{l}\text { Log working hours } \\
\text { per week }\end{array}$} \\
\hline & & (2) & (3) & (4) & (5) \\
\hline & & $\mathrm{FE}$ & FE IV & $\mathrm{FE}$ & FE IV \\
\hline \multirow[t]{2}{*}{ Windfall gains dummy } & -0.00367 & 0.0201 & 0.0563 & 0.000261 & 0.00366 \\
\hline & $(0.00558)$ & $(0.213)$ & $(0.216)$ & $(0.00659)$ & $(0.00687)$ \\
\hline \multirow[t]{2}{*}{ Hourly wage } & & $-0.759^{* * *}$ & -0.0268 & & \\
\hline & & $(0.0385)$ & $(0.330)$ & & \\
\hline \multirow[t]{2}{*}{ Log hourly wage } & & & & $-0.441^{* * *}$ & $-0.149 * *$ \\
\hline & & & & $(0.0103)$ & $(0.0752)$ \\
\hline \multirow[t]{2}{*}{ Age } & $0.0699 * * *$ & $2.651^{* * *}$ & $2.259^{* * *}$ & $0.0474^{* * *}$ & $0.0230^{* * *}$ \\
\hline & $(0.00419)$ & $(0.160)$ & $(0.216)$ & $(0.00532)$ & $(0.00763)$ \\
\hline \multirow[t]{2}{*}{ Age^2 } & $-0.000832^{* * *}$ & $-0.0314^{* * *}$ & $-0.0294^{* * *}$ & $-0.000357^{* * *}$ & $-0.000232^{* * *}$ \\
\hline & $(4.77 e-05)$ & $(0.00182)$ & $(0.00195)$ & $(6.21 e-05)$ & (6.81e-05) \\
\hline \multirow[t]{2}{*}{ Married dummy } & 0.00581 & 0.179 & 0.190 & -0.0135 & -0.0198 \\
\hline & $(0.0105)$ & $(0.402)$ & $(0.420)$ & $(0.0118)$ & $(0.0125)$ \\
\hline \multirow{2}{*}{$\begin{array}{l}\text { Children } 0-6 \text { in } \\
\text { household dummy }\end{array}$} & $-0.0757^{* * *}$ & $-4.828^{* * *}$ & $-4.893^{* * *}$ & $-0.122^{* * *}$ & $-0.130^{* * *}$ \\
\hline & $(0.00915)$ & $(0.350)$ & $(0.362)$ & $(0.0103)$ & $(0.0109)$ \\
\hline \multirow{2}{*}{$\begin{array}{l}\text { Children } 7-15 \text { in } \\
\text { household dummy }\end{array}$} & $-0.0512^{* * *}$ & $-3.309^{* * *}$ & $-3.232^{* * *}$ & $-0.0635^{* * *}$ & $-0.0643^{* * *}$ \\
\hline & $(0.00808)$ & $(0.308)$ & $(0.313)$ & $(0.00932)$ & $(0.00974)$ \\
\hline \multirow[t]{2}{*}{ Constant } & $-0.705^{* * *}$ & $-23.60^{* * *}$ & $-16.21^{* * *}$ & $3.015^{* * *}$ & $3.245^{* * *}$ \\
\hline & $(0.0907)$ & $(3.472)$ & $(4.363)$ & $(0.110)$ & $(0.121)$ \\
\hline Observations & 27988 & 27385 & 27021 & 17736 & 17511 \\
\hline Number of individuals & 5308 & 5284 & 5261 & 4044 & 4021 \\
\hline R-squared & 0.015 & 0.036 & & 0.128 & \\
\hline Hausman test ${ }^{+}$ & & & 0.003 & & 0.001 \\
\hline
\end{tabular}

Standard errors in parentheses, ${ }^{*}$ significant at 10\%; ${ }^{* *}$ significant at $5 \%$; ${ }^{* * *}$ significant at $1 \% .{ }^{+}$Reports p-value of the Hausman test of endogeneity. In IV regression (log) hourly wage is instrumented using two dummies for education, interactions between education dummies and quartic in age and country-year dummies. All regressions include individual fixed-effects.

Finally, in the third specification (Column (4)), we express working hours and wages in logs and only person-year observations with positive working hours and positive wages are included. From an econometric perspective, one should note that a potential problem in this context stems from the fact that when receiving windfall gains individuals may decide to reduce their working effort either by reducing working hours or by dropping out of the labour force, which can generate a selection bias problem. We present the results both from the fixed effect setting (Column (4)) and the instrumental variable estimation with fixed effects (Column (5)).

Table 2 summarizes the findings for the effects of windfall gains on working hours using the whole sample. The empirical evidence is not supportive of theoretical prediction of the life-cycle model that an unanticipated rise in wealth reduces an individual's working hours via a reduction in the marginal utility of wealth, in particular, the coefficients of the windfall gains dummy are not statistically significant. On the other hand, most coefficients of the other control variables have the expected signs and magnitudes and are statistically significant: (i) age has a nonlinear, inverted " $U$ " shaped effect on 
labour supply; (ii) being married tends to increase labour supply; and (iii) having children reduces it. Only hourly wage has a surprising negative effect on working hours, which is reduced after using instrumental variables estimation, but it nevertheless remains negative and significant ${ }^{18}$.

Table 3 reports the results for the sample consisting of men. Again, the coefficients of the windfall gains dummy are not statistically significant. Nevertheless, they are negative, which is in accordance with the theoretical formulation of the life-cycle model. Other controls have coefficients of sensible signs and magnitudes and, in particular, one can see that being married increases men's labour supply.

Table 4 shows the results for the sample consisting of women. Again, in all five specifications, the effects of windfall gains are not statistically significant and are close to zero. These findings are therefore in line with Imbens et al. (2001), who show that the reaction of people to non-earned income does not differ significantly between men and women. Interestingly and in contrast with the results for men, there is an indication that being married reduces women's labour supply.

Due to the number of non-workers included in the sample (and, therefore, zeroes on the dependent variable), one could argue that the equations for working hours conflict with standard labour supply theory: the desired hours of work is equal to actual hours of work when hours of work is positive; but for corner solutions, when hours of work is zero, this cannot be said. In cases where this problem is important, we need to refer to a censored regression model.

To assess the relevance of this feature, we estimate the equation for the working hours per week using a panel data censored model, in particular, the Tobit with fixed effects estimator from Honoré (1992). Table 5 summarizes the results. Column (1) provides the evidence for the full sample, while Columns (2) and (3) display the findings for men and women, respectively. As can be seen, the results are both quantitatively and qualitatively similar to the ones presented in Tables 2, 3 and 4 in that windfall gains do not seem to exert a significant effect on labour supply. Therefore, this suggests that the inclusion of non-workers in the analysis does not bias the estimates and is consistent with the economic theory.

So far we have found no supportive evidence that the receipt of windfall gains has a significant and negative impact on labour supply. This finding however could either reflect that these effects are non-existent, or that they are very small and not well captured in the data. In fact, other researchers have reported that windfall gains (inheritances, financial wealth, housing prices) have, at most, a small impact on labour supply, which in many cases are only marginally statistically significant (Holtz-Eakin et al. 1993; Joulfaian and Wilhelm 1994; Henley 2004). Another possible explanation for the small and not statistically significant results may lay in the fact that the windfall gains dummy used so far does not contain enough information. This can be, for example, because it simply indicates whether an individual has received a windfall gain or not, regardless of the size of the gain. Therefore, in the next sub-section, we split the windfall dummy into three groups: small, medium and large.

\subsection{The effects of small, medium and large windfall gains}

We now introduce into the regression three dummies representing the size of windfall gains that individuals receive: small (less than 10,000 EURO), medium (more than 
Table 5 Effects of windfall gains on working hours

\begin{tabular}{lccc}
\hline Dependent variable: & \multicolumn{3}{c}{ Working hours per week } \\
\cline { 2 - 4 } & All & Men & Women \\
\hline Windfall gains dummy & $\mathbf{( 1 )}$ & $\mathbf{( 2 )}$ & $\mathbf{( 3 )}$ \\
Hourly wage & -0.0464 & -0.1597 & 0.0613 \\
& $(0.230)$ & $(0.2995)$ & $(0.3560)$ \\
Age & $-1.0719^{* * *}$ & $-0.9926^{* * *}$ & $-1.2204^{* * *}$ \\
& $(0.0945)$ & $(0.1259)$ & $(0.1171)$ \\
Age^2 & $5.2488^{* * *}$ & $5.9132^{* * *}$ & $4.4459^{* * *}$ \\
& $(0.2577)$ & $(0.3278)$ & $(0.4038)$ \\
Married dummy & $-0.0617^{* * *}$ & $-0.0688^{* * *}$ & $-0.0530^{* * *}$ \\
& $(0.0030)$ & $(0.0039)$ & $(0.0047)$ \\
Children 0-6 in household dummy & $1.3645^{* * *}$ & $2.1227^{* * *}$ & 0.2216 \\
& $(0.5035)$ & $(0.6251)$ & $(0.7955)$ \\
Children 7-15 in household dummy & $-3.6566^{* * *}$ & $-1.4805^{* * *}$ & $-6.7665^{* * *}$ \\
& $(0.3970)$ & $(0.4610)$ & $(0.6436)$ \\
Observations & $-3.0376^{* * *}$ & $-1.7620^{* * *}$ & $-4.8583^{* * *}$ \\
Number of individuals & $(0.3450)$ & $(0.4437)$ & $(0.5274)$ \\
\hline
\end{tabular}

-Panel data censored regression model (Honoré, 1992).

Standard errors in parentheses, * significant at 10\%; ** significant at $5 \%$; ${ }^{* * *}$ significant at $1 \%$. All regressions include individual fixed-effects.

10,000 EURO but less than 50,000 EURO) and large (50,000 EURO or more). The benchmark for comparison is the time before the windfall gains are received. For example, the coefficient of the small windfall gains dummy tells us by how much working hours decrease (or increase), on average, due to the windfall gain in comparison to the situation where the windfall gain had not been received. According to the theory, the higher the unanticipated windfall gain, the stronger the effect on the marginal utility of wealth and the more negative we expect the effect on labour supply to be. Therefore, we expect the effect of the large windfall gains dummy to be negative and largest in absolute value.

We report the results separately for the whole sample, for men and for women, in Table 6, Table 7 and Table 8, respectively. Column (1) of Table 6 suggests that windfall gains have a negative effect on the probability of being employed. Despite not being statistically significant for small and medium windfall gains, the coefficient associated with large windfall gains is negative and statistically significant. This lends some empirical support to the idea that after receiving large windfall gains, individuals are more likely to drop out of the labour force. As for the other specifications (Columns (2) (5)), the results are not statistically significant, although large windfall gains tend to have the most negative impact on labour supply.

Table 7 displays the results for the sample of men. In all five specifications, not only is the coefficient of large windfall gains the most negative, but it is also statistically significant in all cases. Column (1) indicates that receiving large unanticipated windfall gains induces some men to leave the labour force. Similarly, in specifications with working hours on the left hand side (Columns (2) - (5)) there is a statistically 
Table 6 Effects of small/medium/large windfall gains on working hours - all

\begin{tabular}{|c|c|c|c|c|c|}
\hline \multirow[t]{3}{*}{ Dependent variable: } & \multirow{3}{*}{$\begin{array}{c}\text { Employment } \\
\text { dummy } \\
(1) \\
\text { FE }\end{array}$} & \multicolumn{2}{|c|}{$\begin{array}{l}\text { Working hours } \\
\text { per week }\end{array}$} & \multicolumn{2}{|c|}{$\begin{array}{l}\text { Log working hours } \\
\text { per week }\end{array}$} \\
\hline & & (2) & (3) & (4) & (5) \\
\hline & & $\mathrm{FE}$ & FE IV & $\mathrm{FE}$ & FE IV \\
\hline \multirow[t]{2}{*}{ Small windfall gains dummy } & -0.00283 & -0.132 & -0.114 & 0.00671 & 0.00599 \\
\hline & $(0.00458)$ & $(0.203)$ & $(0.204)$ & $(0.00464)$ & $(0.00476)$ \\
\hline \multirow[t]{2}{*}{ Medium windfall gains dummy } & -0.00597 & -0.0102 & 0.0740 & -0.00356 & -0.00143 \\
\hline & $(0.00494)$ & $(0.218)$ & $(0.221)$ & $(0.00502)$ & $(0.00517)$ \\
\hline \multirow[t]{2}{*}{ Large windfall gains dummy } & $-0.0213^{* *}$ & -0.568 & -0.406 & -0.0137 & -0.00931 \\
\hline & $(0.00835)$ & $(0.371)$ & $(0.378)$ & $(0.00851)$ & $(0.00882)$ \\
\hline \multirow[t]{2}{*}{ Hourly wage } & & $-0.830^{* * *}$ & $-0.427^{* *}$ & & \\
\hline & & $(0.0262)$ & $(0.204)$ & & \\
\hline \multirow[t]{2}{*}{ Log hourly wage } & & & & $-0.404^{* * *}$ & $-0.200^{* * *}$ \\
\hline & & & & $(0.00610)$ & $(0.0471)$ \\
\hline \multirow[t]{2}{*}{ Age } & $0.0824^{* * *}$ & $3.885^{* * *}$ & $3.630^{* * *}$ & $0.0565^{* * *}$ & $0.0388^{* * *}$ \\
\hline & $(0.00272)$ & $(0.121)$ & $(0.150)$ & $(0.00295)$ & $(0.00464)$ \\
\hline \multirow[t]{2}{*}{$\mathrm{Age}^{\wedge} 2$} & $-0.000985^{* * *}$ & $-0.0452^{* * *}$ & $-0.0439 * * *$ & $-0.000488^{* * *}$ & $-0.000391^{* * *}$ \\
\hline & (3.09e-05) & $(0.00137)$ & $(0.00142)$ & (3.40e-05) & $(3.88 \mathrm{e}-05)$ \\
\hline \multirow[t]{2}{*}{ Married dummy } & $0.0131^{*}$ & $1.213^{* * *}$ & $1.159^{* * *}$ & $0.0148^{* *}$ & 0.00942 \\
\hline & $(0.00680)$ & $(0.301)$ & $(0.312)$ & $(0.00671)$ & $(0.00708)$ \\
\hline \multirow{2}{*}{$\begin{array}{l}\text { Children } 0-6 \text { in } \\
\text { household dummy }\end{array}$} & $-0.0518^{* * *}$ & $-2.848^{* * *}$ & $-2.970^{* * *}$ & $-0.0491^{* * *}$ & $-0.0534^{* * *}$ \\
\hline & $(0.00571)$ & $(0.253)$ & $(0.259)$ & $(0.00560)$ & $(0.00584)$ \\
\hline \multirow{2}{*}{$\begin{array}{l}\text { Children } 7-15 \text { in } \\
\text { household dummy }\end{array}$} & $-0.0427^{* * *}$ & $-2.323^{* * *}$ & $-2.338^{* * *}$ & $-0.0294 * * *$ & $-0.0293^{* * *}$ \\
\hline & $(0.00519)$ & $(0.230)$ & $(0.233)$ & $(0.00518)$ & (0.00533) \\
\hline \multirow[t]{2}{*}{ Constant } & $-0.848^{* * *}$ & $-41.78^{* * *}$ & $-36.56^{* * *}$ & $2.971^{* * *}$ & $3.126^{* * *}$ \\
\hline & $(0.0587)$ & $(2.609)$ & (3.085) & $(0.0616)$ & $(0.0679)$ \\
\hline Observations & 54164 & 53011 & 52348 & 40239 & 39789 \\
\hline Number of individuals & 10395 & 10357 & 10322 & 8735 & 8700 \\
\hline R-squared & 0.024 & 0.049 & & 0.127 & \\
\hline Hausman test ${ }^{+}$ & & & 0.000 & & 0.000 \\
\hline
\end{tabular}

Standard errors in parentheses, ${ }^{*}$ significant at $10 \%$; ${ }^{*}$ significant at $5 \%$; ${ }^{* *}$ significant at $1 \%$. ${ }^{+}$Reports $p$-value of the Hausman test of endogeneity. In IV regression (log) hourly wage is instrumented using two dummies for education, interactions between education dummies and quartic in age and country-year dummies. All regressions include individual fixed-effects.

significant and negative effect of large windfall gains on working hours. Column (2) captures both external and internal margins of adjustment: on average, receiving an unanticipated windfall gain of 50,000 EUR or more reduces the labour supply of men by 1.3 hours per week. Since average working hours for men in the sample are equal to 39.2 hours per week, this represents on average a $3.4 \%$ reduction in working hours. In Column (4), where only the internal margin is considered, the evidence suggests that the large windfall gains reduce working hours by $2.1 \%$. Since only the adjustment of working hours conditional on working is taken into account, the effect is plausibly smaller.

The results for women in Table 8, on the other hand, are not supportive of the idea that windfall gains reduce labour supply. None of the coefficients on windfall gains 
Table 7 Effects of small/medium/large windfall gains on working hours - men

\begin{tabular}{|c|c|c|c|c|c|}
\hline \multirow[t]{3}{*}{ Dependent variable: } & \multirow{3}{*}{$\begin{array}{c}\text { Employment } \\
\text { dummy } \\
(1) \\
\text { FE }\end{array}$} & \multicolumn{2}{|c|}{$\begin{array}{l}\text { Working hours } \\
\text { per week }\end{array}$} & \multicolumn{2}{|c|}{$\begin{array}{l}\text { Log working hours } \\
\text { per week }\end{array}$} \\
\hline & & (2) & (3) & (4) & (5) \\
\hline & & $\mathrm{FE}$ & FE IV & $\mathrm{FE}$ & FE IV \\
\hline \multirow[t]{2}{*}{ Small windfall gains dummy } & -0.00104 & -0.177 & -0.126 & 0.00557 & 0.00517 \\
\hline & $(0.00563)$ & $(0.301)$ & $(0.303)$ & $(0.00502)$ & $(0.00515)$ \\
\hline \multirow[t]{2}{*}{ Medium windfall gains dummy } & -0.00617 & 0.0221 & 0.111 & 0.00139 & 0.00153 \\
\hline & $(0.00610)$ & $(0.326)$ & $(0.329)$ & $(0.00552)$ & $(0.00566)$ \\
\hline \multirow[t]{2}{*}{ Large windfall gains dummy } & $-0.0306^{* * *}$ & $-1.337^{* *}$ & $-0.966^{*}$ & $-0.0208^{* *}$ & $-0.0184^{*}$ \\
\hline & $(0.0103)$ & $(0.552)$ & $(0.560)$ & $(0.00927)$ & $(0.00953)$ \\
\hline \multirow[t]{2}{*}{ Hourly wage } & & $-0.878^{* * *}$ & $-0.795^{* * *}$ & & \\
\hline & & $(0.0360)$ & $(0.219)$ & & \\
\hline \multirow[t]{2}{*}{ Log hourly wage } & & & & $-0.368^{* * *}$ & $-0.196^{* * *}$ \\
\hline & & & & $(0.00704)$ & $(0.0463)$ \\
\hline \multirow[t]{2}{*}{ Age } & $0.0954^{* * *}$ & $5.191^{* * *}$ & $5.065^{* * *}$ & $0.0620^{* * *}$ & $0.0473^{* * *}$ \\
\hline & $(0.00338)$ & $(0.181)$ & $(0.206)$ & $(0.00323)$ & $(0.00490)$ \\
\hline \multirow[t]{2}{*}{$\mathrm{Age}^{\wedge} 2$} & $-0.00115^{* * *}$ & $-0.0601^{* * *}$ & $-0.0592^{* * *}$ & $-0.000577^{* * *}$ & $-0.000495^{* * *}$ \\
\hline & $(3.84 \mathrm{e}-05)$ & $(0.00205)$ & $(0.00209)$ & (3.69e-05) & $(4.23 e-05)$ \\
\hline \multirow[t]{2}{*}{ Married dummy } & $0.0199^{* *}$ & $2.138^{* * *}$ & $2.055^{* * *}$ & $0.0350^{* * *}$ & $0.0295^{* * *}$ \\
\hline & $(0.00843)$ & $(0.449)$ & $(0.460)$ & $(0.00748)$ & $(0.00784)$ \\
\hline \multirow{2}{*}{$\begin{array}{l}\text { Children 0-6 in } \\
\text { household dummy }\end{array}$} & $-0.0311^{* * *}$ & $-1.221^{* * *}$ & $-1.418^{* * *}$ & $-6.81 e-05$ & -0.00316 \\
\hline & $(0.00684)$ & $(0.366)$ & $(0.372)$ & $(0.00602)$ & $(0.00625)$ \\
\hline \multirow{2}{*}{$\begin{array}{l}\text { Children } 7-15 \text { in } \\
\text { household dummy }\end{array}$} & $-0.0357^{* * *}$ & $-1.505^{* * *}$ & $-1.586^{* * *}$ & -0.00606 & -0.00580 \\
\hline & $(0.00640)$ & $(0.341)$ & $(0.346)$ & $(0.00566)$ & $(0.00582)$ \\
\hline \multirow[t]{2}{*}{ Constant } & $-0.983^{* * *}$ & $-60.20^{* * *}$ & $-57.13^{* * *}$ & $2.960^{* * *}$ & $3.075^{* * *}$ \\
\hline & $(0.0730)$ & (3.914) & (4.333) & $(0.0677)$ & $(0.0737)$ \\
\hline Observations & 26176 & 25626 & 25327 & 22503 & 22278 \\
\hline Number of individuals & 5087 & 5073 & 5061 & 4691 & 4679 \\
\hline R-squared & 0.044 & 0.070 & & 0.141 & \\
\hline Hausman test $^{+}$ & & & 0.000 & & 0.034 \\
\hline
\end{tabular}

Standard errors in parentheses, ${ }^{*}$ significant at $10 \%$; ${ }^{*}$ significant at $5 \%$; ${ }^{* *}$ significant at $1 \%$. ${ }^{+}$Reports $p$-value of the Hausman test of endogeneity. In IV regression (log) hourly wage is instrumented using two dummies for education, interactions between education dummies and quartic in age and country-year dummies. All regressions include individual fixed-effects.

dummies are statistically significant, and many of them are nonnegative. In light of the fact that women are usually considered as being less attached to the labour market than men, this result is surprising. One would indeed expect the effect of windfall gains to be stronger and more negative for women. For instance, Henley (2004) finds a significant adjustment in hours worked to unanticipated financial gains for both men and women, but the largest impact occurs for women. In addition, the author shows that while men seem to make a (positive) adjustment in hours to housing losses but not a (negative) adjustment to gains, for women the reverse is true. On the other hand, Imbens et al. (2001) estimate the marginal propensity to earn out of unearned income and find that it does not differ significantly between men and women. Joulfaian and 
Table 8 Effects of small/medium/large windfall gains on working hours - women

\begin{tabular}{|c|c|c|c|c|c|}
\hline \multirow[t]{3}{*}{ Dependent variable: } & \multirow{3}{*}{$\begin{array}{c}\text { Employment } \\
\text { dummy } \\
(1) \\
\text { FE }\end{array}$} & \multicolumn{2}{|c|}{$\begin{array}{l}\text { Working hours } \\
\text { per week }\end{array}$} & \multicolumn{2}{|c|}{$\begin{array}{l}\text { Log working hours } \\
\text { per week }\end{array}$} \\
\hline & & (2) & (3) & (4) & (5) \\
\hline & & $\mathrm{FE}$ & FE IV & $\mathrm{FE}$ & FE IV \\
\hline \multirow[t]{2}{*}{ Small windfall gains dummy } & -0.00442 & -0.0920 & -0.127 & 0.00806 & 0.00690 \\
\hline & $(0.00712)$ & $(0.272)$ & $(0.275)$ & $(0.00845)$ & $(0.00877)$ \\
\hline \multirow[t]{2}{*}{ Medium windfall gains dummy } & -0.00583 & -0.0449 & 0.0757 & -0.0111 & -0.00479 \\
\hline & $(0.00765)$ & $(0.291)$ & $(0.297)$ & $(0.00897)$ & $(0.00943)$ \\
\hline \multirow[t]{2}{*}{ Large windfall gains dummy } & -0.0123 & 0.211 & 0.183 & -0.00496 & 0.00332 \\
\hline & $(0.0129)$ & $(0.495)$ & $(0.508)$ & $(0.0154)$ & $(0.0163)$ \\
\hline \multirow[t]{2}{*}{ Hourly wage } & & $-0.759 * * *$ & -0.0251 & & \\
\hline & & $(0.0385)$ & $(0.330)$ & & \\
\hline \multirow[t]{2}{*}{ Log hourly wage } & & & & $-0.442^{* * *}$ & $-0.148^{* *}$ \\
\hline & & & & $(0.0103)$ & $(0.0754)$ \\
\hline \multirow[t]{2}{*}{ aAge } & $0.0702^{* * *}$ & $2.660^{* * *}$ & $2.270^{* * *}$ & $0.0476^{* * *}$ & $0.0231^{* * *}$ \\
\hline & $(0.00419)$ & $(0.160)$ & $(0.215)$ & $(0.00532)$ & $(0.00763)$ \\
\hline \multirow[t]{2}{*}{$\mathrm{Age}^{\wedge} 2$} & $-0.000833^{* * *}$ & $-0.0315^{* * *}$ & $-0.0294^{* * *}$ & $-0.000357^{* * *}$ & $-0.000231^{* * *}$ \\
\hline & $(4.77 e-05)$ & $(0.00182)$ & $(0.00195)$ & $(6.21 e-05)$ & (6.81e-05) \\
\hline \multirow[t]{2}{*}{ Married dummy } & 0.00593 & 0.178 & 0.192 & -0.0135 & -0.0199 \\
\hline & $(0.0105)$ & $(0.402)$ & $(0.419)$ & $(0.0118)$ & $(0.0126)$ \\
\hline \multirow{2}{*}{$\begin{array}{l}\text { Children 0-6 in } \\
\text { household dummy }\end{array}$} & $-0.0758^{* * *}$ & $-4.824^{* * *}$ & $-4.893^{* * *}$ & $-0.122^{* * *}$ & $-0.130^{* * *}$ \\
\hline & $(0.00915)$ & $(0.350)$ & $(0.363)$ & $(0.0103)$ & $(0.0109)$ \\
\hline \multirow{2}{*}{$\begin{array}{l}\text { Children 7-15 in } \\
\text { household dummy }\end{array}$} & $-0.0513^{* * *}$ & $-3.308^{* * *}$ & $-3.232^{* * *}$ & $-0.0636^{* * *}$ & $-0.0643^{* * *}$ \\
\hline & $(0.00808)$ & $(0.308)$ & $(0.313)$ & $(0.00932)$ & $(0.00974)$ \\
\hline \multirow[t]{2}{*}{ Constant } & $-0.715^{* * *}$ & $-23.90^{* * *}$ & $-16.58^{* * *}$ & $3.009^{* * *}$ & $3.237^{* * *}$ \\
\hline & $(0.0906)$ & $(3.466)$ & $(4.341)$ & $(0.110)$ & $(0.121)$ \\
\hline Observations & 27988 & 27385 & 27021 & 17736 & 17511 \\
\hline Number of individuals & 5308 & 5284 & 5261 & 4044 & 4021 \\
\hline R-squared & 0.015 & 0.036 & & 0.129 & \\
\hline Hausman test $^{+}$ & & & 0.005 & & 0.004 \\
\hline
\end{tabular}

Standard errors in parentheses, * significant at $10 \%$; ${ }^{* *}$ significant at $5 \%$; ${ }^{* * *}$ significant at $1 \% .{ }^{+}$Reports p-value of the Hausman test of endogeneity. In IV regression (log) hourly wage is instrumented using two dummies for education, interactions between education dummies and quartic in age and country-year dummies. All regressions include individual fixed-effects.

Wilhelm (1994) also show that the hours' reduction by married women is of the same order of magnitude as men's.

As before, we also estimate the equation for the working hours per week where we control for the size of the windfall gain using the Tobit with fixed effects estimator from Honore (1992). Columns (1), (2) and (3) summarize the results for the full sample, for men and for women, respectively. Again, the empirical findings are broadly in line with the evidence shown in Tables 6, 7, 8 and 9 implying that the inclusion of individuals for which the number of hours of work is zero does not affect the estimates of the impact of windfall gains on labour supply.

A potential reason why the effects do not come through very strongly in the analysis above is due to heterogeneity in the effects of windfall gains. The effects of windfall 
Table 9 Effects of small/medium/large windfall gains on working hours

\begin{tabular}{|c|c|c|c|}
\hline \multirow[t]{3}{*}{ Dependent variable: } & \multicolumn{3}{|c|}{ Working hours per week } \\
\hline & All & Men & Women \\
\hline & $(1)$ & $(2)$ & (3) \\
\hline \multirow[t]{2}{*}{ Small windfall gains dummy } & -0.1340 & -0.1872 & -0.0909 \\
\hline & $(0.3123)$ & $(0.3940)$ & $(0.4996)$ \\
\hline \multirow[t]{2}{*}{ Medium windfall gains dummy } & 0.0344 & 0.0238 & 0.0119 \\
\hline & $(0.3328)$ & $(0.4442)$ & $(0.4989)$ \\
\hline \multirow[t]{2}{*}{ Large windfall gains dummy } & -0.5920 & -1.3047 & -0.3672 \\
\hline & $(0.6441)$ & $(0.8415)$ & $(0.9742)$ \\
\hline \multirow[t]{2}{*}{ Hourly wage } & $-1.0714^{* * *}$ & $-0.9916^{* * *}$ & $-1.2209^{* * *}$ \\
\hline & $(0.0946)$ & $(0.1261)$ & $(0.1171)$ \\
\hline \multirow[t]{2}{*}{ Age } & $5.2572^{* * *}$ & $5.9145^{* * *}$ & $4.4542^{* * *}$ \\
\hline & $(0.2574)$ & $(0.3274)$ & $(0.4028)$ \\
\hline \multirow[t]{2}{*}{ Age $\wedge 2$} & $-0.0617^{* * *}$ & $-0.0688^{* * *}$ & $-0.0530^{* * *}$ \\
\hline & $(0.0030)$ & $(0.0039)$ & $(0.0047)$ \\
\hline \multirow[t]{2}{*}{ Married dummy } & $1.3741^{* * *}$ & $2.1346^{* * *}$ & 0.2170 \\
\hline & $(0.5038)$ & $(0.6252)$ & $(0.7956)$ \\
\hline \multirow[t]{2}{*}{ Children 0-6 in household dummy } & $-3.6637^{* * *}$ & $-1.4922^{* * *}$ & $-6.760^{* * *}$ \\
\hline & $(0.3971)$ & $(0.4613)$ & $(0.6432)$ \\
\hline \multirow[t]{2}{*}{ Children $7-15$ in household dummy } & $-3.0409^{* * *}$ & $-1.7673^{* * *}$ & $-48554^{* * *}$ \\
\hline & $(0.3450)$ & $(0.4435)$ & $(0.5274)$ \\
\hline Observations & 53011 & 25626 & 27385 \\
\hline Number of individuals & 10357 & 5073 & 5284 \\
\hline
\end{tabular}

gains may possibly depend on personal characteristics in an important way, so that the impact cancels out across different individuals. For example, an old worker may retire from the labour market after receiving the windfall gain, whereas a young employed worker may use it as a starting capital for a new business, become self-employed and increase his labour supply ${ }^{19}$. In order to assess the potential heterogeneity in the effects of windfall gains, in the next sub-section we interact the windfall gains dummy with several personal characteristics.

\subsection{The effects of windfall gains and interactions}

In order to see whether the effects of unanticipated positive wealth shocks differ with respect to personal characteristics, we interact the windfall gains dummy with the other regressors. As discussed above, if the effects of windfall gains depend on personal characteristics and if, in addition, they cancel each other out across individuals, then this would explain why in the previous regressions the effects were small and often not statistically significant.

In Table 10, we report the results for the whole sample. Note that the coefficient in front of the windfall gain dummy alone simply represents the effect of windfall gains when all other controls are set to zero. In most cases, the coefficients of the interaction terms are statistically significant. Column (1) displays the results for the probability of 
Table 10 Effects of windfall gains and interactions - all

\begin{tabular}{|c|c|c|c|c|c|}
\hline \multirow[t]{3}{*}{ Dependent variable: } & \multirow{3}{*}{$\begin{array}{c}\text { Employment } \\
\text { dummy } \\
\text { (1) } \\
\text { FE }\end{array}$} & \multicolumn{2}{|c|}{$\begin{array}{l}\text { Working hours } \\
\text { per week }\end{array}$} & \multicolumn{2}{|c|}{$\begin{array}{l}\text { Log working hours } \\
\text { per week }\end{array}$} \\
\hline & & (2) & (3) & (4) & (5) \\
\hline & & $\mathrm{FE}$ & FE IV & $\mathrm{FE}$ & FE IV \\
\hline \multirow[t]{2}{*}{ Windfall gains dummy } & $-0.351^{* * *}$ & $-11.64^{* * *}$ & $-11.52^{* * *}$ & 0.0568 & $-6.97 e-05$ \\
\hline & $(0.0582)$ & $(2.579)$ & $(2.633)$ & $(0.0631)$ & $(0.0670)$ \\
\hline \multirow[t]{2}{*}{ Hourly wage } & & $-0.912^{* * *}$ & -0.158 & & \\
\hline & & $(0.0334)$ & $(0.300)$ & & \\
\hline \multirow{2}{*}{$\begin{array}{l}\text { Interaction of windfall gains } \\
\text { with wage }\end{array}$} & & $0.117^{* * *}$ & -0.187 & & \\
\hline & & $(0.0287)$ & $(0.118)$ & & \\
\hline \multirow[t]{2}{*}{ Log hourly wage } & & & & $-0.399^{* * *}$ & $-0.193^{* * *}$ \\
\hline & & & & $(0.00714)$ & $(0.0475)$ \\
\hline \multirow{2}{*}{$\begin{array}{l}\text { Interaction of windfall gains } \\
\text { with log wage }\end{array}$} & & & & -0.00797 & 0.00363 \\
\hline & & & & $(0.00617)$ & $(0.0196)$ \\
\hline \multirow[t]{2}{*}{ Age } & $0.0700^{* * *}$ & $3.371^{* * *}$ & $2.969^{* * *}$ & $0.0529^{* * *}$ & $0.0324^{* * *}$ \\
\hline & $(0.00378)$ & $(0.168)$ & $(0.207)$ & $(0.00410)$ & $(0.00569)$ \\
\hline \multirow{2}{*}{$\begin{array}{l}\text { Interaction of windfall gains } \\
\text { with age }\end{array}$} & $0.0186^{* * *}$ & $0.637^{* * *}$ & $0.726^{* * *}$ & -0.000138 & 0.00192 \\
\hline & $(0.00291)$ & $(0.129)$ & $(0.134)$ & $(0.00318)$ & $(0.00339)$ \\
\hline \multirow[t]{2}{*}{$\operatorname{Age}^{\wedge} 2$} & $-0.000843^{* * *}$ & $-0.0390^{* * *}$ & $-0.0367^{* * *}$ & $-0.000440^{* * *}$ & $-0.000312^{* * *}$ \\
\hline & $(4.53 e-05)$ & $(0.00201)$ & (0.00209) & (4.97e-05) & $(5.52 \mathrm{e}-05)$ \\
\hline \multirow{2}{*}{$\begin{array}{l}\text { Interaction of windfall gains } \\
\text { with age^2 }\end{array}$} & $-0.000217^{* * *}$ & $-0.00792^{* * *}$ & $-0.00869^{* * *}$ & $-7.41 e-06$ & $-3.52 e-05$ \\
\hline & $(3.45 e-05)$ & $(0.00153)$ & $(0.00157)$ & (3.82e-05) & $(4.02 \mathrm{e}-05)$ \\
\hline \multirow[t]{2}{*}{ Married dummy } & $0.0398^{* * *}$ & $2.082^{* * *}$ & $2.115^{* * *}$ & $0.0268^{* * *}$ & $0.0221^{* * *}$ \\
\hline & $(0.00790)$ & $(0.350)$ & $(0.361)$ & $(0.00781)$ & $(0.00824)$ \\
\hline \multirow{2}{*}{$\begin{array}{l}\text { Interaction of windfall gains } \\
\text { with married dummy }\end{array}$} & $-0.0436^{* * *}$ & $-1.505^{* * *}$ & $-1.619^{* * *}$ & $-0.0233^{* * *}$ & $-0.0244^{* * *}$ \\
\hline & $(0.00694)$ & $(0.308)$ & $(0.316)$ & $(0.00702)$ & $(0.00724)$ \\
\hline \multirow{2}{*}{$\begin{array}{l}\text { Children 0-6 in hhold } \\
\text { dummy }\end{array}$} & $-0.0425^{* * *}$ & $-1.978^{* * *}$ & $-2.251^{* * *}$ & $-0.0332^{* * *}$ & $-0.0371^{* * *}$ \\
\hline & $(0.00740)$ & $(0.328)$ & $(0.336)$ & $(0.00732)$ & $(0.00760)$ \\
\hline \multirow{2}{*}{$\begin{array}{l}\text { Interaction of windfall gains } \\
\text { with children 0-6 dummy }\end{array}$} & -0.00801 & $-1.223^{* * *}$ & $-0.947^{* * *}$ & $-0.0247^{* * *}$ & $-0.0247^{* * *}$ \\
\hline & $(0.00783)$ & $(0.347)$ & $(0.358)$ & $(0.00783)$ & $(0.00827)$ \\
\hline \multirow[t]{2}{*}{ Children 7-15 in hhold dummy } & q & $-2.135^{* * *}$ & $-2.149^{* * *}$ & $-0.0303^{* * *}$ & $-0.0312^{* * *}$ \\
\hline & $(0.00676)$ & $(0.299)$ & $(0.304)$ & $(0.00679)$ & $(0.00699)$ \\
\hline \multirow{2}{*}{$\begin{array}{l}\text { Interaction of windfall gains } \\
\text { with children } 7-15 \text { dummy }\end{array}$} & 0.00822 & 0.0116 & 0.0738 & 0.00755 & 0.00931 \\
\hline & $(0.00755)$ & $(0.334)$ & $(0.339)$ & $(0.00756)$ & $(0.00778)$ \\
\hline \multirow[t]{2}{*}{ Constant } & $-0.610^{* * *}$ & $-32.06^{* * *}$ & $-25.22^{* * *}$ & $3.009^{* * *}$ & $3.222^{* * *}$ \\
\hline & $(0.0765)$ & (3.395) & (3.928) & $(0.0807)$ & $(0.0897)$ \\
\hline Observations & 54164 & 53011 & 52348 & 40239 & 39789 \\
\hline Number of individuals & 10395 & 10357 & 10322 & 8735 & 8700 \\
\hline R-squared & 0.026 & 0.051 & & 0.128 & \\
\hline Hausman test ${ }^{+}$ & & & 0.001 & & 0.000 \\
\hline
\end{tabular}

Standard errors in parentheses, * significant at 10\%; ${ }^{* *}$ significant at 5\%; ${ }^{* * *}$ significant at $1 \% .{ }^{+}$Reports $p$-value of the Hausman test of endogeneity. In IV regression (log) hourly wage is instrumented using two dummies for education, interactions between education dummies and quartic in age and country-year dummies. All regressions include individual fixed-effects. 
being employed. Looking at the interactions, age has a " $U$ " shaped curve effect: at younger and older ages, the effect of windfall gains on participation is the most negative. This is in line with evidence reported by Holtz-Eakin et al. (1993) and Imbens et al. (2001).

Being married also makes the negative effect of windfall gains on participation stronger. Thus, married people are more likely to reduce their labour supply. One possible explanation for this is that married people have less to worry about their income situation, as they have a partner who usually earns an income. Such behaviour can also be explained by the fact that if people like to spend leisure in groups, then they are more likely to consume leisure when they have someone to spend the leisure with.

In Columns (2) and (3) where total working hours are used as a dependent variable, results are similar: (i) there is an indication of a non-linear effect of age; (ii) being married makes the effect of windfall gains more negative; and (iii) similarly, having children of age 0-6 leads to a larger decrease in working hours, indicating that parents of young children do not drop out of the labour force after receiving windfall gains, but they seek shorter working hours. Columns (4) and (5) show the results for the sample with positive hours worked. They confirm that being married and having small children makes the effect of windfall gains more negative.

Table 11 reports the empirical findings for the sample of men. In Columns (1), (2) and (3), one can see that if they are of younger or older age, have young children or are married, then windfall gains reduce the probability of being employed. However, when we take away the adjustment along the external margin (columns (4) and (5)), the effects largely become not statistically significant, except for the effects of having young children.

Table 12 provides similar findings for women. In Column (1), where the probability of being employed is explored, there is a " $U$ " shaped effect of age and a statistically significant negative effect of being married. The coefficients on the interactions of children dummies with windfall gains are not statistically significant. In the regressions with working hours on the left hand side (columns (2) and (3)) the results show that women with young children tend to reduce working hours after the receipt of windfall gains. Columns (4) and (5) also confirm this finding.

In order to obtain a better understanding of the heterogeneity in the effects of windfall gains and how they depend on personal characteristics, Table 13 reports the predicted effects of windfall gains on labour supply by various types of individuals. We compute the effects of windfall gains for 8 hypothetical types of individuals. We start by choosing four different age groups: $25,30,40$ or 55 years. We choose the following types: (i) individuals of age 25 are single and have no children; (ii) individuals of age 30 are either single with no children, or married with one child of age $0-6$, (iii) individuals of age 40 can be single without children, married without children, or married with one child of age $0-6$ and one child of age 7-15; (iv) individuals of age 55 can either be single or married, but they do not have any young children.

In those specifications where hourly wage is one of the regressors, predicted effects are computed at the mean wage in the sample. Specification (1) represents effects from participation regressions, specification (2) reports the FE IV regressions with working hours per week on the left hand side, and specification (3) reports effects from FE IV regressions with log working hours as the dependent variable. In brackets we also 
Table 11 Effects of windfall gains and interactions - men

\begin{tabular}{|c|c|c|c|c|c|}
\hline \multirow[t]{3}{*}{ Dependent variable: } & \multirow{2}{*}{$\begin{array}{c}\text { Employment } \\
\text { dummy } \\
\text { (1) }\end{array}$} & \multicolumn{2}{|c|}{$\begin{array}{l}\text { Working hours } \\
\text { per week }\end{array}$} & \multicolumn{2}{|c|}{$\begin{array}{l}\text { Log working hours } \\
\text { per week }\end{array}$} \\
\hline & & (2) & (3) & (4) & (5) \\
\hline & $\mathrm{FE}$ & $\mathrm{FE}$ & FE IV & $\mathrm{FE}$ & FE IV \\
\hline \multirow[t]{2}{*}{ Windfall gains dummy } & $-0.292^{* * *}$ & $-12.85^{* * *}$ & $-12.35^{* * *}$ & -0.00101 & -0.0175 \\
\hline & $(0.0719)$ & $(3.857)$ & (3.929) & $(0.0688)$ & $(0.0718)$ \\
\hline \multirow[t]{2}{*}{ Hourly wage } & & $-0.933^{* * *}$ & -0.510 & & \\
\hline & & $(0.0446)$ & $(0.334)$ & & \\
\hline \multirow{2}{*}{$\begin{array}{l}\text { Interaction of windfall } \\
\text { gains with wage }\end{array}$} & & $0.0820^{* *}$ & -0.212 & & \\
\hline & & $(0.0393)$ & $(0.144)$ & & \\
\hline \multirow[t]{2}{*}{ Log hourly wage } & & & & $-0.366^{* * *}$ & $-0.185^{* * *}$ \\
\hline & & & & $(0.00810)$ & $(0.0465)$ \\
\hline \multirow{2}{*}{$\begin{array}{l}\text { Interaction of windfall } \\
\text { gains with log wage }\end{array}$} & & & & -0.00325 & -0.0191 \\
\hline & & & & $(0.00685)$ & $(0.0201)$ \\
\hline \multirow[t]{2}{*}{ Age } & $0.0862^{* * *}$ & $4.614^{* * *}$ & $4.361^{* * *}$ & $0.0560^{* * *}$ & $0.0388^{* * *}$ \\
\hline & $(0.00470)$ & $(0.252)$ & $(0.288)$ & $(0.00448)$ & $(0.00612)$ \\
\hline \multirow{2}{*}{$\begin{array}{l}\text { Interaction of windfall } \\
\text { gains with age }\end{array}$} & $0.0154^{* * *}$ & $0.687^{* * *}$ & $0.750^{* * *}$ & 0.00231 & 0.00469 \\
\hline & $(0.00360)$ & $(0.193)$ & $(0.200)$ & $(0.00347)$ & $(0.00373)$ \\
\hline \multirow[t]{2}{*}{$\mathrm{Age}^{\wedge} 2$} & $-0.00104^{* * *}$ & $-0.0531^{* * *}$ & $-0.0516^{* * *}$ & $-0.000498^{* * *}$ & $-0.000386^{* * *}$ \\
\hline & $(5.60 e-05)$ & $(0.00300)$ & $(0.00307)$ & $(5.39 \mathrm{e}-05)$ & $(6.03 e-05)$ \\
\hline \multirow{2}{*}{$\begin{array}{l}\text { Interaction of windfall } \\
\text { gains with age }{ }^{\wedge}\end{array}$} & $-0.000180^{* * *}$ & $-0.00862^{* * *}$ & $-0.00898^{* * *}$ & $-3.98 \mathrm{e}-05$ & $-6.76 e-05$ \\
\hline & $(4.26 e-05)$ & $(0.00228)$ & $(0.00233)$ & $(4.14 \mathrm{e}-05)$ & $(4.38 \mathrm{e}-05)$ \\
\hline \multirow[t]{2}{*}{ Married dummy } & $0.0353^{* * *}$ & $2.579 * * *$ & $2.514^{* * *}$ & $0.0387^{* * *}$ & $0.0344^{* * *}$ \\
\hline & $(0.00992)$ & $(0.529)$ & $(0.542)$ & $(0.00884)$ & $(0.00924)$ \\
\hline \multirow{2}{*}{$\begin{array}{l}\text { Interaction of windfall gains } \\
\text { with married dummy }\end{array}$} & $-0.0251^{* * *}$ & -0.735 & -0.758 & -0.00908 & -0.0100 \\
\hline & $(0.00904)$ & $(0.485)$ & $(0.494)$ & $(0.00824)$ & $(0.00850)$ \\
\hline \multirow[t]{2}{*}{ Children 0-6 in hhold dummy } & $-0.0152^{*}$ & -0.328 & -0.726 & $0.0130^{*}$ & 0.00975 \\
\hline & $(0.00897)$ & $(0.479)$ & $(0.488)$ & $(0.00790)$ & $(0.00817)$ \\
\hline \multirow{2}{*}{$\begin{array}{l}\text { Interaction of windfall gains } \\
\text { with children 0-6 dummy }\end{array}$} & $-0.0214^{* *}$ & $-1.235^{* *}$ & $-0.893^{*}$ & $-0.0224^{* * *}$ & $-0.0210^{* *}$ \\
\hline & $(0.00955)$ & $(0.510)$ & $(0.519)$ & $(0.00845)$ & $(0.00881)$ \\
\hline \multirow{2}{*}{$\begin{array}{l}\text { Children 7-15 in hhold } \\
\text { dummy }\end{array}$} & $-0.0321^{* * *}$ & $-1.285^{* * *}$ & $-1.408^{* * *}$ & 0.00313 & 0.00272 \\
\hline & $(0.00839)$ & $(0.448)$ & $(0.455)$ & $(0.00749)$ & $(0.00770)$ \\
\hline \multirow{2}{*}{$\begin{array}{l}\text { Interaction of windfall gains } \\
\text { with children } 7-15 \text { dummy }\end{array}$} & -0.000463 & -0.112 & 0.0145 & -0.0125 & -0.0105 \\
\hline & $(0.00939)$ & $(0.502)$ & $(0.507)$ & $(0.00834)$ & $(0.00855)$ \\
\hline \multirow[t]{2}{*}{ Constant } & $-0.807^{* * *}$ & $-49.14^{* * *}$ & $-44.71^{* * *}$ & $3.053^{* * *}$ & $3.198^{* * *}$ \\
\hline & $(0.0951)$ & $(5.093)$ & $(5.583)$ & $(0.0887)$ & $(0.0976)$ \\
\hline Observations & 26176 & 25626 & 25327 & 22503 & 22278 \\
\hline Number of individuals & 5087 & 5073 & 5061 & 4691 & 4679 \\
\hline R-squared & 0.045 & 0.072 & & 0.141 & \\
\hline Hausman test ${ }^{+}$ & & & 0.001 & & 0.048 \\
\hline
\end{tabular}

Standard errors in parentheses, ${ }^{*}$ significant at $10 \%$; ${ }^{*}$ significant at $5 \%$; ${ }^{* * *}$ significant at $1 \%$. ${ }^{+}$Reports $p$-value of the Hausman test of endogeneity. In IV regression (log) hourly wage is instrumented using two dummies for education, interactions between education dummies and quartic in age and country-year dummies. All regressions include individual fixed-effects. 
Table 12 Effects of windfall gains and interactions - women

\begin{tabular}{|c|c|c|c|c|c|}
\hline \multirow[t]{3}{*}{ Dependent variable: } & \multirow{3}{*}{$\begin{array}{l}\text { Employment dummy } \\
\qquad \begin{array}{l}\text { (1) } \\
\mathrm{FE}\end{array}\end{array}$} & \multicolumn{2}{|c|}{$\begin{array}{l}\text { Working hours per } \\
\text { week }\end{array}$} & \multicolumn{2}{|c|}{$\begin{array}{l}\text { Log working hours per } \\
\text { week }\end{array}$} \\
\hline & & (2) & (3) & (4) & (5) \\
\hline & & $\mathrm{FE}$ & FE IV & $\mathrm{FE}$ & FE IV \\
\hline \multirow[t]{2}{*}{ Windfall gains dummy } & $-0.387^{* * *}$ & $-7.540^{* *}$ & $-8.464^{* *}$ & $0.213^{*}$ & 0.0951 \\
\hline & (0.0909) & $(3.465)$ & (3.528) & $(0.115)$ & $(0.125)$ \\
\hline \multirow[t]{2}{*}{ Hourly wage } & & $-0.919^{* * *}$ & -0.224 & & \\
\hline & & $(0.0512)$ & $(0.425)$ & & \\
\hline \multirow{2}{*}{$\begin{array}{l}\text { Interaction of windfall } \\
\text { gains with wage }\end{array}$} & & $0.210^{* * *}$ & 0.115 & & \\
\hline & & $(0.0442)$ & $(0.177)$ & & \\
\hline \multirow[t]{2}{*}{ Log hourly wage } & & & & $-0.438^{* * *}$ & $-0.170^{* *}$ \\
\hline & & & & $(0.0124)$ & $(0.0786)$ \\
\hline \multirow{2}{*}{$\begin{array}{l}\text { Interaction of windfall } \\
\text { gains with log wage }\end{array}$} & & & & -0.00632 & 0.0393 \\
\hline & & & & $(0.0113)$ & $(0.0383)$ \\
\hline \multirow[t]{2}{*}{ Age } & $0.0558^{* * *}$ & $2.361^{* * *}$ & $1.944^{* * *}$ & $0.0511^{* * *}$ & $0.0246^{* * *}$ \\
\hline & $(0.00586)$ & $(0.224)$ & $(0.283)$ & $(0.00741)$ & $(0.00950)$ \\
\hline \multirow{2}{*}{$\begin{array}{l}\text { Interaction of windfall } \\
\text { gains with age }\end{array}$} & $0.0204^{* * *}$ & $0.401^{* *}$ & $0.482^{* * *}$ & -0.00848 & -0.00642 \\
\hline & $(0.00453)$ & $(0.173)$ & $(0.182)$ & $(0.00581)$ & $(0.00626)$ \\
\hline \multirow[t]{2}{*}{$\mathrm{Age}^{\wedge} 2$} & $-0.000670^{* * *}$ & $-0.0278^{* * *}$ & $-0.0251^{* * *}$ & $-0.000394^{* * *}$ & $-0.000246^{* *}$ \\
\hline & (7.03e-05) & $(0.00268)$ & $(0.00284)$ & (9.10e-05) & (9.82e-05) \\
\hline \multirow{2}{*}{$\begin{array}{l}\text { Interaction of windfall } \\
\text { gains with age^2 }\end{array}$} & $-0.000236^{* * *}$ & $-0.00500^{* *}$ & $-0.00596^{* * *}$ & $9.49 e-05$ & $6.62 \mathrm{e}-05$ \\
\hline & $(5.41 e-05)$ & $(0.00206)$ & $(0.00214)$ & (7.04e-05) & (7.51e-05) \\
\hline \multirow[t]{2}{*}{ Married dummy } & $0.0403^{* * *}$ & $1.212^{* * *}$ & $1.279^{* * *}$ & 0.00334 & -0.00508 \\
\hline & $(0.0121)$ & $(0.464)$ & $(0.482)$ & $(0.0135)$ & $(0.0145)$ \\
\hline \multirow{2}{*}{$\begin{array}{l}\text { Interaction of windfall } \\
\text { gains with married dummy }\end{array}$} & $-0.0549^{* * *}$ & $-1.788^{* * *}$ & $-1.803^{* * *}$ & $-0.0315^{* * *}$ & $-0.0288^{* *}$ \\
\hline & $(0.0103)$ & $(0.396)$ & $(0.414)$ & $(0.0117)$ & $(0.0125)$ \\
\hline \multirow[t]{2}{*}{ Children 0-6 in hhold dummy } & $-0.0739^{* * *}$ & $-4.075^{* * *}$ & $-4.127^{* * *}$ & $-0.100^{* * *}$ & $-0.107^{* * *}$ \\
\hline & $(0.0117)$ & $(0.448)$ & $(0.460)$ & $(0.0134)$ & $(0.0141)$ \\
\hline \multirow{2}{*}{$\begin{array}{l}\text { Interaction of windfall gains } \\
\text { with children 0-6 dummy }\end{array}$} & 0.00775 & $-1.070^{* *}$ & $-1.017^{* *}$ & $-0.0330^{* *}$ & $-0.0340^{* *}$ \\
\hline & $(0.0124)$ & $(0.475)$ & $(0.492)$ & $(0.0144)$ & $(0.0154)$ \\
\hline \multirow[t]{2}{*}{ Children $7-15$ in hhold dummy } & $-0.0564^{* * *}$ & $-3.356^{* * *}$ & $-3.230^{* * *}$ & $-0.0778^{* * *}$ & $-0.0807^{* * *}$ \\
\hline & $(0.0105)$ & $(0.400)$ & $(0.406)$ & $(0.0121)$ & $(0.0127)$ \\
\hline \multirow{2}{*}{$\begin{array}{l}\text { Interaction of windfall gains } \\
\text { with children } 7-15 \text { dummy }\end{array}$} & 0.0176 & 0.406 & 0.353 & $0.0333^{* *}$ & $0.0353^{* *}$ \\
\hline & $(0.0117)$ & $(0.447)$ & $(0.454)$ & $(0.0135)$ & $(0.0141)$ \\
\hline \multirow[t]{2}{*}{ Constant } & $-0.440^{* * *}$ & $-18.02^{* * *}$ & $-10.49^{* *}$ & $2.912^{* * *}$ & $3.231^{* * *}$ \\
\hline & $(0.118)$ & $(4.520)$ & (5.328) & $(0.145)$ & $(0.159)$ \\
\hline Observations & 27988 & 27385 & 27021 & 17736 & 17511 \\
\hline Number of individuals & 5308 & 5284 & 5261 & 4044 & 4021 \\
\hline R-squared & 0.017 & 0.039 & & 0.130 & \\
\hline Hausman test ${ }^{+}$ & & & 0.007 & & 0.007 \\
\hline
\end{tabular}

Standard errors in parentheses, *significant at 10\%; **significant at 5\%; ${ }^{* * *}$ significant at 1\%. ${ }^{+}$Reports p-value of the Hausman test of endogeneity. In IV regression (log) hourly wage is instrumented using two dummies for education, interactions between education dummies and quartic in age and country-year dummies. All regressions include individual fixed-effects. 
Table 13 Effects of windfall gains on labour supply (coefficients associated with the interaction terms representing different hypothetical individuals)

\begin{tabular}{|c|c|c|c|c|c|c|c|c|c|}
\hline \multirow{4}{*}{$\begin{array}{l}\text { Dependent } \\
\text { variable }\end{array}$} & \multicolumn{3}{|c|}{ All } & \multicolumn{3}{|c|}{ Men } & \multicolumn{3}{|c|}{ Women } \\
\hline & $\begin{array}{l}\text { Employment } \\
\text { dummy }\end{array}$ & $\begin{array}{l}\text { Working hours } \\
\text { per week }\end{array}$ & $\begin{array}{l}\text { Log working hours } \\
\text { per week }\end{array}$ & $\begin{array}{l}\text { Employment } \\
\text { dummy }\end{array}$ & $\begin{array}{l}\text { Working hours } \\
\text { per week }\end{array}$ & $\begin{array}{l}\text { Log working hours } \\
\text { per week }\end{array}$ & $\begin{array}{l}\text { Employment } \\
\text { dummy }\end{array}$ & $\begin{array}{l}\text { Working hours } \\
\text { per week }\end{array}$ & $\begin{array}{l}\text { Log working hours } \\
\text { per week }\end{array}$ \\
\hline & (1) & (2) & (3) & (1) & (2) & (3) & (1) & (2) & (3) \\
\hline & $\mathrm{FE}$ & FE IV & FE IV & $\mathrm{FE}$ & FE IV & FE IV & $\mathrm{FE}$ & FE IV & FE IV \\
\hline \multirow{2}{*}{$\begin{array}{l}25 \text { yrs, single, } \\
\text { no children }\end{array}$} & $-0.021^{* *}$ & -0.259 & $0.033^{* * *}$ & $-0.020^{*}$ & -1.002 & 0.019 & -0.025 & 0.682 & $0.049^{* *}$ \\
\hline & $(0.034)$ & $(0.609)$ & $(0.005)$ & $(0.091)$ & $(0.182)$ & $(0.173)$ & (0.119) & $(0.311)$ & $(0.016)$ \\
\hline \multirow{2}{*}{$\begin{array}{l}30 \text { yrs, single, } \\
\text { no children }\end{array}$} & $0.012^{*}$ & $0.979^{* * *}$ & $0.033^{* * *}$ & 0.007 & 0.279 & $0.024^{* *}$ & 0.012 & $1.455^{* * *}$ & $0.035^{* *}$ \\
\hline & $(0.093)$ & $(0.006)$ & $(0.000)$ & $(0.411)$ & $(0.597)$ & $(0.011)$ & (0.318) & $(0.002)$ & $(0.011)$ \\
\hline \multirow{2}{*}{$\begin{array}{l}30 \text { yrs, married, } \\
\text { with one child }\end{array}$} & $-0.039^{* * *}$ & $-1.587^{* * *}$ & $-0.016^{* *}$ & $-0.040^{* * *}$ & $-1.372^{* * *}$ & -0.007 & $-0.035^{* * *}$ & $-1.365^{* * *}$ & $-0.028^{*}$ \\
\hline & $(0.000)$ & $(0.000)$ & $(0.041)$ & $(0.000)$ & $(0.010)$ & $(0.410)$ & $(0.002)$ & $(0.003)$ & $(0.054)$ \\
\hline \multirow{2}{*}{$\begin{array}{l}40 \text { yrs, single, } \\
\text { no children }\end{array}$} & $0.046^{* * *}$ & $2.152^{* * *}$ & $0.028^{* * *}$ & $0.034^{* * *}$ & $1.494^{* * *}$ & $0.023^{* * *}$ & $0.050^{* * *}$ & $2.107^{* * *}$ & 0.017 \\
\hline & $(0.000)$ & $(0.000)$ & $(0.000)$ & $(0.000)$ & $(0.003)$ & $(0.007)$ & $(0.000)$ & $(0.000)$ & $(0.202)$ \\
\hline \multirow{2}{*}{$\begin{array}{l}40 \text { yrs, married, } \\
\text { no children }\end{array}$} & 0.003 & $0.533^{*}$ & 0.003 & 0.009 & 0.736 & $0.013^{*}$ & -0.005 & 0.305 & -0.011 \\
\hline & $(0.701)$ & $(0.083)$ & $(0.650)$ & $(0.275)$ & $(0.110)$ & $(0.090)$ & $(0.666)$ & $(0.455)$ & $(0.371)$ \\
\hline \multirow{2}{*}{$\begin{array}{l}40 \text { yrs, married } \\
\text { with children }\end{array}$} & 0.003 & -0.340 & -0.012 & -0.013 & -0.143 & $-0.018^{*}$ & 0.021 & -0.358 & -0.010 \\
\hline & $(0.764)$ & $(0.427)$ & $(0.225)$ & $(0.275)$ & (0.819) & $(0.087)$ & $(0.165)$ & $(0.540)$ & $(0.589)$ \\
\hline \multirow{2}{*}{$\begin{array}{l}55 \text { yrs, single, } \\
\text { no children }\end{array}$} & $0.016^{*}$ & 0.652 & 0.006 & 0.008 & -0.051 & -0.002 & 0.020 & 0.853 & 0.015 \\
\hline & $(0.069)$ & (0.109) & $(0.535)$ & $(0.471)$ & $(0.934)$ & $(0.826)$ & $(0.142)$ & $(0.108)$ & (0.394) \\
\hline \multirow{2}{*}{$\begin{array}{l}55 \text { yrs, married, } \\
\text { no children }\end{array}$} & $-0.028^{* * *}$ & $-0.966^{* * *}$ & $-0.018^{* *}$ & $-0.017^{* *}$ & $-0.809^{*}$ & -0.013 & $-0.035^{* * *}$ & $-0.950^{* *}$ & -0.013 \\
\hline & $(0.000)$ & $(0.002)$ & $(0.032)$ & $(0.042)$ & $(0.093)$ & $(0.167)$ & $(0.001)$ & $(0.020)$ & $(0.384)$ \\
\hline
\end{tabular}

p-values in parentheses; testing the null whether linear combination of coefficients equal to zero. ${ }^{*}$ significant at $10 \%$; **significant at $5 \%$; ***significant at $1 \%$. (1) Employment dummy as dependent variable, $\mathrm{FE}$; (2) Working hours per week as dependent variable, FE IV; (3) Log working hours per week as dependent variable, FE IV. In (2) and (3) wages are also included in the regression; in these cases effects are calculated at the value of the average wage in the sample (all, men or women). All regressions include individual fixed-effects. 
report p-values from the Wald test of whether the computed predicted effects are statistically different from zero.

For young single people who have no children (first row of Table 13), receiving windfall gains reduces the probability of participating in the labour force. This can be seen, for example, in column (1), where the coefficient is -0.021 . A possible explanation for this finding is that after winning an unanticipated windfall young people may decide to prolong their education and finance it with the money they have won. However, as specification (3) suggests, conditional on being employed, windfall gains increase the labour supply of young people, perhaps inducing young people to become selfemployed and work more.

For individuals of age 30 and with no children, there is a positive effect of windfall gains on the probability of participating in the labour market and also on working hours conditional on working. On the other hand, for individuals of the same age who are married and have children of young age, the effects of windfall gains on labour supply are negative, with effects being strongly negative for both men and women.

In the case of individuals aged 40 with no spouse and no children, there is a positive effect of windfall gains on labour supply. Weekly working hours, on average, increase by 2.152 hours (specification (2)) or, conditional on working, for $0.028 \log$ hours, approximately $2.8 \%$ (specification (3)). This piece of evidence can again be related with the rise in probability of becoming self-employed as discussed in Taylor (2001). Interestingly, however, these effects do not appear for individuals of age 40 who are married, especially if they have young children.

As for the effects of windfall gains on the labour supply of married individuals aged 55 , they tend to be statistically significant and negative. The impact of windfall gains on the employment participation (specification (1)) is equal to -0.028 and the effect on weekly working hours (specification (2)) is equal to -0.966 . These general patterns are similar for men and for women.

Summing up, several interesting results emerge when we interact personal characteristics with windfall gains. First, the effects of windfall gains operate both at the external and internal margin, but they tend to be stronger at the external margin. This suggests that after receiving windfall gains, people adjust their labour supply mainly by dropping out of the labour force, rather than by reducing their hours worked. Second, there is evidence that for some individuals (e.g., for single middle-aged individuals with no children), effects on working hours can be positive. And third, for young and old people as well as for married individuals with young children, windfall gains tend to have the most strongly negative impact on labour supply.

Finally, in Table 14, we find support for the behaviour suggested by Taylor (2001). More specifically, we show that winning windfall gains increases the probability of becoming self-employed, especially, for men ${ }^{20}$. With regard to the amount of the windfall gains, the effects become stronger for larger windfall gains. In the case of women, the impact is generally not statistically significant. However, for very large windfall gains, there is also a positive impact on probability of becoming self-employed, at $10 \%$ confidence level.

This set of results is extremely interesting and has important academic and policy implications. Indeed, even if the gains are expected by individuals, it is unlikely that they can be used as collateral for their credit for a potential business investment. If this is 
Table 14 Effects of windfall gains on probability of becoming self-employed

\begin{tabular}{|c|c|c|c|c|c|c|}
\hline & \multicolumn{6}{|c|}{ Dependent variable: self-employed dummy } \\
\hline & All & Men & Women & All & Men & Women \\
\hline & (1) & (2) & (3) & (4) & (5) & (6) \\
\hline \multirow{2}{*}{$\begin{array}{l}\text { Windfall gains } \\
\text { dummy }\end{array}$} & $0.00807^{* * *}$ & $0.0122^{* * *}$ & 0.00399 & & & \\
\hline & $(0.00231)$ & $(0.00358)$ & $(0.00297)$ & & & \\
\hline \multirow{2}{*}{$\begin{array}{l}\text { Small windfall gains } \\
\text { dummy }\end{array}$} & & & & 0.00198 & 0.00599 & -0.00195 \\
\hline & & & & $(0.00294)$ & $(0.00454)$ & $(0.00378)$ \\
\hline \multirow{2}{*}{$\begin{array}{l}\text { Medium windfall } \\
\text { gains dummy }\end{array}$} & & & & $0.00900^{* * *}$ & $0.0147^{* * *}$ & 0.00345 \\
\hline & & & & $(0.00317)$ & $(0.00492)$ & $(0.00406)$ \\
\hline \multirow{2}{*}{$\begin{array}{l}\text { Large windfall gains } \\
\text { dummy }\end{array}$} & & & & $0.0144^{* * *}$ & $0.0175^{* *}$ & $0.0120^{*}$ \\
\hline & & & & $(0.00535)$ & $(0.00832)$ & $(0.00685)$ \\
\hline \multirow[t]{2}{*}{ Age } & $0.0208^{* * *}$ & $0.0312^{* * *}$ & $0.0114^{* * *}$ & $0.0212^{* * *}$ & $0.0316^{* * *}$ & $0.0117^{* * *}$ \\
\hline & $(0.00175)$ & $(0.00272)$ & $(0.00222)$ & $(0.00174)$ & $(0.00272)$ & $(0.00222)$ \\
\hline \multirow[t]{2}{*}{$\mathrm{Age}^{\wedge} 2$} & $-0.000243^{* * *}$ & $-0.000359^{* * *}$ & $-0.000139^{* * *}$ & $-0.000245^{* * *}$ & $-0.000361^{* * *}$ & $-0.000140^{* * *}$ \\
\hline & $(1.99 e-05)$ & (3.09e-05) & $(2.53 e-05)$ & $(1.99 e-05)$ & (3.09e-05) & $(2.53 e-05)$ \\
\hline \multirow[t]{2}{*}{ Married dummy } & $0.0219^{* * *}$ & $0.0335^{* * *}$ & $0.00945^{*}$ & $0.0219^{* * *}$ & $0.0334^{* * *}$ & $0.00944^{*}$ \\
\hline & $(0.00437)$ & $(0.00680)$ & $(0.00560)$ & $(0.00437)$ & $(0.00680)$ & $(0.00560)$ \\
\hline \multirow{2}{*}{$\begin{array}{l}\text { Children 0-6 in } \\
\text { household dummy }\end{array}$} & -0.000748 & -0.00464 & 0.00135 & -0.000758 & -0.00475 & 0.00147 \\
\hline & $(0.00367)$ & $(0.00552)$ & $(0.00486)$ & $(0.00367)$ & $(0.00552)$ & $(0.00487)$ \\
\hline \multirow{2}{*}{$\begin{array}{l}\text { Children } 7-15 \text { in } \\
\text { household dummy }\end{array}$} & -0.00284 & -0.00471 & -0.00221 & -0.00280 & -0.00469 & -0.00214 \\
\hline & $(0.00333)$ & $(0.00516)$ & $(0.00429)$ & $(0.00333)$ & $(0.00516)$ & $(0.00429)$ \\
\hline \multirow[t]{2}{*}{ Constant } & $-0.316^{* * *}$ & $-0.490^{* * *}$ & $-0.156^{* * *}$ & $-0.328^{* * *}$ & $-0.502^{* * *}$ & $-0.169^{* * *}$ \\
\hline & $(0.0378)$ & $(0.0591)$ & $(0.0482)$ & $(0.0377)$ & $(0.0589)$ & $(0.0481)$ \\
\hline Observations & 54210 & 26177 & 28033 & 54210 & 26177 & 28033 \\
\hline Number of individuals & 10397 & 5088 & 5309 & 10397 & 5088 & 5309 \\
\hline R-squared & 0.005 & 0.011 & 0.002 & 0.006 & 0.011 & 0.002 \\
\hline
\end{tabular}

Standard errors in parentheses, ${ }^{*}$ significant at $10 \%$; **ignificant at $5 \%$; ***significant at $1 \%$. All regressions include individual fixed-effects.

the case and the arrival of windfall gains relaxes the credit constraint, then we would expect a reaction among individuals on the labour market and an increase in the probability of becoming self-employed. Our findings seem to corroborate this idea, thereby, suggesting that by reducing the tightness of credit constraints for potential entrepreneurs, the rates of self-employment may increase. Therefore, the elimination of credit rationing problems can provide a boost to labour supply (Lehmann 1995).

Another possible interpretation for the positive link between windfall gains and labour supply can be attributed to attitudes towards risk and how they differ across own and borrowed funds. For instance, Taylor (2001) suggests that when entrepreneurial activity and effort are substitutes, the receipt of a windfall gain by a liquidityconstrained entrepreneur raises future self-employment utility and can lead to higher self-employment income. As for the case of a liquidity-unconstrained entrepreneur, the windfall gain may end up reducing income as a result of a focus on less profitable aspects of the business, which are compensated by an increase in job satisfaction. Ogaki and Zhang (2001) find empirical evidence corroborating the existence of a decreasing relative risk aversion. Sousa (forthcoming) highlights that the proportion of risky assets 
that is held by investors increases after a positive shock to wealth, which suggests the existence of habit-formation, loss aversion or wealth-dependent preferences ${ }^{21}$.

\section{Conclusion}

In this paper, we investigate whether European workers adjust labour supply (that is, labour market participation and working hours) in response to windfall gains. According to the life-cycle model of labour supply, unanticipated gains in non-earned income are expected to have negative effects on labour supply. We use information from the European Household Panel for the 1994 to 2001 period to shed some light on the question of interest.

We find weak evidence that individuals react to windfall gains by reducing their working hours. The effects, however, seem to be small and statistically significant only in the case of large windfall gains. In addition, individuals seem to adjust their labour supply mostly along the external margin, by dropping out of the labour force, rather than by reducing their working hours while staying in employment. The results and conclusions are robust to different specifications and they are not affected by the choice of which measure of wage is used on the right hand side: the hourly wage or the net monthly wage.

When we allow for heterogeneity of the effects across individuals, the results suggest that the impact of windfall gains on labour supply: (i) is more important for young and old individuals, (ii) is most negative for married individuals with young children, (iii) but can be positive for single individuals aged around 40 years. The last effect can be explained by the effect of windfall gains on reducing liquidity constraints in capital markets and thus encouraging people to become self-employed.

In light of the prominent role played by small businesses and self-employment in terms of job creation, our results suggest that policies towards the provision of better access to credit can boost labour market participation. In fact, the credit squeeze observed in the aftermath of the financial crisis of 2008-2009 was particularly detrimental for small companies and self-employed people, who are less likely to benefit from government loan programs. In this context, the main challenge that governments and central banks face is to responsibly manage the lending risk (Martin 2011). Other potential channels explaining the positive link between between self-employment and receipt of "windfall" income include the possibility that richer families are more likely to give inheritances or individuals from richer families could be more likely to start their own businesses.

In addition, the fact that the size of the windfall gains matters for the significance of the effects on labour supply implies that policymakers should pay a particular attention to this specific feature when designing optimal inheritance and real estate taxes or taxes on windfall gains.

Finally, in a work close to ours, Brown et al. (2010) suggest that a shock to wealth can have a positive impact not only on the labour supply, but also on the probability of retirement by active workers and households nearing retirement age, with the effect being stronger for larger and unexpected inheritances. As a result, the current paper can provide valuable insights about the likely response of labour supply to wealth changes, such as those associated with reforms in the Social Security. This, in turn, may prove useful in the context of the build-up of long-term macroeconomic projections. 


\section{Endnotes}

${ }^{1}$ Azmat et al. (2006) also use the European Community Household Panel Survey, but in the context of analysing the large gender gap in unemployment rates. Notably, the authors show that interactions between the differences in human capital accumulation by gender and labour market institutions play a major role. In a similar context, Joshi et al. (2007) argue that women's education and experience rather than a movement towards equal treatment play a special role in gender pay differences. Mumford and Smith $(2007,2009)$ find that the gender earnings gap can also be largely explained by the workplace in which the employee works.

${ }^{2}$ By using a panel framework, we face the difficulty that we merge a sample of countries that may have heterogeneous labour markets. For instance, in the case of two countries where wages are determined in collective bargaining and employment/hours according to the labour-demand function, with different degrees of union power, these two countries would pick different points on the labour-demand function and a negative relation between wages and employment/hours would occur. Despite this, we note that our models are estimated by fixed-effects. Therefore, we control for unobserved heterogeneity. Individual fixed effects, in a nested way, control also for country level characteristics.

${ }^{3}$ The fact that the data are collected on household level, but the decision unit is at individual level might bias the results. For instance, if husband receives a big gift, he may not be responsive by changing his regular hours of work. However, the wife may reduce her labour supply given the positive income shock on the household. Therefore, the results based on individual decisions might attenuate the true effect, since both the husband and wife are recorded as having received the gift only that the wife actually responded.

${ }^{4}$ For a review of the literature examining the impact of wealth shocks on retirement decisions, see Coile and Levine (2006) and Gustman et al. (2010).

${ }^{5}$ In cases where individuals change households (e.g. get married) and they receive windfall gains only after they have moved to a new household, they are recorded as recipients of windfall gains together with their partner. Naturally, individuals from the initial household have not received any windfall gains. Should the individual move households again with a new partner, for example, then he would still be recorded as a recipient of windfall gains, but his new partner would not.

${ }^{6}$ Similarly, income variables are also recorded for "year prior to the survey". On the other hand, net monthly wage and other variables are recorded for "the time of the interview".

${ }^{7}$ How much information the individual possesses at the time of the interview of course depends on the relative timings of windfall gains and survey interview, but on average there is a $50 \%$ chance that the individual had already received the windfall gains.

${ }^{8}$ For instance, Imbens et al. (2001) have about 237 winners, Joulfaian and Wilhelm (1994) have 439 heirs in their sample, Holtz-Eakin et al. (1993) have 2,700 married couples and 1632 individuals in their sample, and Henley (2004) has around 5,400 men and women included.

${ }^{9}$ Interestingly, Joshi et al. (1996) show that the presence of children reduces full-time employment among women. Similarly, Joshi (1998) highlights the impact of child-rearing on women's time use. 
${ }^{10}$ Hourly wage is a measure of offered wages in the labour market. Reported data is in purchasing power parity units in order to be comparable across countries. Hourly wage is calculated from net monthly wage given in the data, divided by weekly working hours times 4.33 to correct for the average number of weeks in one month. All hourly wages lower than 1 Euro or higher than 100 Euros are put to missing. Wages of people who do not work or wages otherwise missing are then imputed. For those individuals of which wage information is available in some periods but not in others, the average wage of the individual is imputed in other periods. Other wages are imputed using a regression equation separately for men and women using age, age squared, married dummy, two education dummies and wave and country dummies as regressors.

${ }^{11}$ The observed differences between winners and non-winners from Table 1 could of course reflect simply differences across countries. However, when we checked differences in means after excluding some countries, with much lower percentage of winners, the magnitudes and conclusions were similar.

${ }^{12}$ Non-work income contains both the "usual non-work income" of an individual and the received windfall gain. Since we are not able to know the exact size of the windfall gain, the two components cannot be disentangled. Therefore, we exclude the non-work income from the regression Equation.

${ }^{13}$ When we plot household income over time by size of windfall gains, it can be seen that the discrete jump in income in the period the windfall gains are received is, as expected, larger for the group that receives larger gains. This figure is available upon request.

${ }^{14}$ Pencavel (1986) also highlights the endogeneity of nonwage income. In the context of our framework we consider windfall gains as unanticipated and exogenous.

${ }^{15}$ We highlight that several factors may impact on labour supply. For instance, inheritance laws or inheritance taxes can affect the magnitude of the income gift for rich families, hence, making the "anticipated" impact on labour supply smaller. Despite this, we note that by considering a fixed-effects regressor, we are able to control for unobserved heterogeneity.

${ }^{16}$ In our sample, about $25 \%$ of people change their employment status at least once.

${ }^{17}$ In all cases in the paper where we estimated the linear probability model we also checked the results using logit specification with fixed effects. Results were very similar with the same conclusions.

${ }^{18}$ This is perhaps due to the income effect being stronger than the substitution effect, although empirically this remains an unresolved issue. All regressions have also been run using net monthly wage instead. In this case, the coefficient on the wage variable was always positive in both the OLS and instrumental variables specifications. However, the coefficients on the other variables and the conclusions regarding the effects of windfall gains were very similar to the results from the specifications which included the hourly wage.

${ }^{19}$ Taylor (2001) argues that windfall gains can contribute to the relaxation of the liquidity constraints in capital markets and finds evidence that they increase the probability of becoming self-employed.

${ }^{20}$ Including interaction terms supports the story that men aged about 40 years have a higher probability of becoming self-employed after winning a windfall gain. The same applies to married men vis-à-vis single men.

${ }^{21}$ Donkers et al. (2001) show that agents become more risk averse as the level of their wealth increases. Sousa (2010) designs an experiment to assess the effects of small- 
scale changes in wealth on risk attitudes, and finds that money given prior to risky choices does not influence preferences.

\section{Competing interests}

The IZA Journal of Labor Economics is committed to the IZA Guiding Principles of Research Integrity. The authors declare that they observed these principles.

\section{Acknowledgements}

The authors acknowledge the helpful comments made by the Editor, Pierre Cahuc, and two anonymous referees. Responsible Editor: Pierre Cahuc.

\section{Author details}

${ }^{1} \mathrm{OECD}, 2$ rue Andre Pascal, 75775 Paris Cedex 16, France. ${ }^{2}$ Department of Economics and Economic Policies Research Unit (NIPE), University of Minho, Campus of Gualtar, 4710-057 Braga, Portugal. ${ }^{3}$ London School of Economics, LSE Alumni Association, Houghton Street, London WC2 2AE, UK.

Received: 7 October 2013 Accepted: 9 January 2014

Published: 10 Feb 2014

\section{References}

Altonji JG (1986) Substitution in labour supply: evidence from micro data. J Polit Econ 94(3):Part 2, S176-S215 Azmat G, Güell M, Manning A (2006) Gender gaps in unemployment rates in OECD countries. J Labour Econ 24(1):1-37 Blanchflower DG, Oswald AJ (1998) What makes an entrepreneur? J Labour Econ 16:26-60 Bodkin R (1959) Windfall income and consumption. Am Econ Rev 49:602-614

Brown JR, Coile CC, Weisbenner SJ (2010) The effect of inheritance receipt on retirement. Rev Econ Stat 92(2):425-434 Burke AE, Fitzroy FR, Nolan MA (1997) Entrepreneurial choice and performance: a re-appraisal of liquidity and human capital constraints. University of St Andrews, Centre for Research into Industry, Enterprise, Finance and the Firm, Discussion Paper No. 9723, Fife, UK

Coile CC, Levine P (2006) Bulls, bears, and retirement behaviour. Ind Lab Relat Rev 59(3):408-429

Donkers B, Melenberg B, van Soest A (2001) Estimating risk attitudes using lotteries: a large sample approach. J Risk Uncertain 22(2):165-195

Gustman AL, Steinmeier TL, Tabatabai N (2010) What the stock market decline means for the financial security and retirement choices of the near-retirement population. J Econ Perspect 24(1):161-182

Heckman JJ, MaCurdy TE (1980) A life-cycle model of female labour supply. Rev Econ Stud 47:47-74

Henley A (2004) Hours price shocks, windfall gains and hours of work: British evidence. Oxf Bull Econ Stat 66(4):439-456

Holtz-Eakin D, Joulfaian D, Rosen H (1993) The Carnegie conjecture: some empirical evidence. Q J Econ 108(2):413-435

Honoré BE (1992) Trimmed lad and least squares estimation of truncated and censored regression models with fixed effects. Econometrica 60(3):533-565

Imbens G, Rubin D, Sacerdote B (2001) Estimating the effect of unearned income on labour earnings, savings, and consumption: evidence from a survey of lottery players. Am Econ Rev 91(4):778-794

Joshi H (1998) The opportunity costs of childbearing: more than mothers' business. J Popul Econ 11:161-183

Joshi H, Macran S, Dex S (1996) Employment after childbearing and women's subsequent labour force participation: Evidence from the British 1958 birth cohort. J Popul Econ 9:325-348.

Joshi H, Makepeace G, Dolton P (2007) More or less unequal? Evidence on the pay of men and women from the British Birth Cohort Studies. Gend Work Organ 14(1):37-55

Joulfaian D (2006) Inheritance and saving. National Bureau of Economic Research, NBER Working Paper No. 12569, Washigton DC, USA

Joulfaian D, Wilhelm M (1994) Inheritance and labour supply. J Hum Resour 29(4):1205-1234

Kaplan HR (1988) Gambling among lottery winners: before and after the big score. J Gambl Behav 4:171-182

Lehmann H (1995) Active labour market policies in the OECD and in selected transition economies. World Bank, Policy Research Working Paper No. 1502, Washington DC, USA

Martin B (2011) The credit gap: Easing the squeeze on the smallest businesses. Progressive Policy Institute, Policy Brief, Washington DC, USA, pp 1-12

Mumford K, Smith PN (2007) The gender earnings gap in Britain: including the workplace. Manchester School 75(6):653-672

Mumford K, Smith PN (2009) What determines the part-time and gender earnings gaps in Britain: evidence from the workplace. Oxf Econ Pap 61:i56-i75

Ogaki M, Zhang Q (2001) Decreasing relative risk aversion and tests of risk sharing. Econometrica 69(2):515-526

Pencavel J (1986) Labour supply of men: a survey. In: Ashenfelter O, Layard R (eds) Handbook of Labour Economics, 1, Amsterdam, North-Holland, pp 3-102

Sousa RM (forthcoming) What is the impact of wealth shocks on asset allocation? Quant Finance

Sousa S (2010) Small-scale changes in wealth and attitudes toward risk. The University of Nottingham, Centre for Decision Research \& Experimental Economics, CeDEx Discussion Paper, Nottingham, UK

Taylor MP (2001) Self-employment and windfall gains in Britain: evidence from panel data. Economica 68(272):539-565

10.1186/2193-8997-3-1

Cite this article as: Sila and Sousa: Windfall gains and labour supply: evidence from the European household panel. IZA Journal of Labor Economics 2014, 3:1 